\title{
The APC/C ubiquitin ligase: from cell biology to tumorigenesis
}

\section{Clara Penas ${ }^{1}$, Vimal Ramachandran ${ }^{1}$ and Nagi George Ayad ${ }^{1,2}$ *}

1 John P. Hussman Institute for Human Genomics, University of Miami Miller School of Medicine, Miami, FL, USA

${ }^{2}$ Department of Psychiatry and Behavioral Sciences, University of Miami Miller School of Medicine, Miami, FL, USA

\section{Edited by:}

Wenyi Wei, Beth Israel Deaconess Medical Center, USA

Reviewed by:

Hui-Kuan Lin, The University of Texas MD Anderson Cancer Center, USA Lixin Wan, Beth Israel Deaconess Medical Center, USA

*Correspondence:

Nagi George Ayad, Department of Psychiatry and Behavioral Sciences, University of Miami Miller School of Medicine, 1501 Northwest 10th Avenue, Miami, FL, USA

e-mail:nayad@med.miami.edu
The ubiquitin proteasome system (UPS) is required for normal cell proliferation, vertebrate development, and cancer cell transformation. The UPS consists of multiple proteins that work in concert to target a protein for degradation via the $26 \mathrm{~S}$ proteasome. Chains of an 8.5-kDa protein called ubiquitin are attached to substrates, thus allowing recognition by the $26 S$ proteasome. Enzymes called ubiquitin ligases or E3s mediate specific attachment to substrates. Although there are over 600 different ubiquitin ligases, the Skp1-Cullin-F-box (SCF) complexes and the anaphase promoting complex/cyclosome (APC/C) are the most studied. SCF involvement in cancer has been known for some time while APC/C's cancer role has recently emerged. In this review we will discuss the importance of APC/C to normal cell proliferation and development, underscoring its possible contribution to transformation. We will also examine the hypothesis that modulating a specific interaction of the APC/C may be therapeutically attractive in specific cancer subtypes. Finally, given that the APC/C pathway is relatively new as a cancer target, therapeutic interventions affecting APC/C activity may be beneficial in cancers that are resistant to classical chemotherapy.

Keywords: ubiquitin, cell cycle, differentiation, cancer, ubiquitin ligase, cancer therapy

\section{INTRODUCTION}

Any discussion of the anaphase promoting complex/cyclosome (APC/C) pathway as a possible therapeutic target has to start with the question of what makes APC/C unique among the many ubiquitin ligases present in human cells. On one level APC/C is mechanistically similar to the Skp1-Cullin-F-box (SCF) ubiquitin ligases where there are core subunits and an adaptor protein that directly binds to a substrate. In SCFs, the four subunits are Skp1 (scaffold protein), Cull (scaffold protein), RING-finger component $(\mathrm{Rbx} 1)$, and the variable adaptor protein or F-box protein that recognizes substrates (Zheng et al., 2002). In APC/C there are 13 subunits as well as variable adaptor proteins termed Cdc20 (or Fizzy; Fzy), Cdh1 (or Fizzy-related; Fzr), Cortex, Ama1, or Mfr1

Abbreviations: APC/C, anaphase promoting complex/cyclosome; bHLH, basic helix-loop-helix; BMP, bone morphogenetic protein; Cdc20, cell division cycle protein 20 or Fizzy, Fzy; Cdh1, Cdc20 homolog 1, or Fizzy-related, Fzr; Cdk, cyclin-dependent kinase; CK1, casein kinase 1; D-boxes, destruction boxes; E1, ubiquitin-activating enzyme; E2, ubiquitin-conjugating enzyme; E3, ubiquitin ligases; Emil, early mitotic inhibitor-1/Rcal; HAT, histone acetyltransferase; HDAC histone deacetylase; HEC1, high expression in cancer 1; Id1, inhibitor of DNA binding 1; Id2, inhibitor of DNA binding 2, also known as inhibitor of differentiation 2; JNK, c-Jun NH2-terminal kinase; MAK, male germ cell-associated kinase; MCM, minichromosome maintenance; MEF, mouse embryonic fibroblast; MR, methionine-arginine; NAALADase, $N$-acetylated alpha-linked acidic peptidase; Nek2, NIMA-related kinase 2; NGF, nerve growth factor; OSCC, oral squamous cell carcinomas; PC, proteasome/cyclosome; PCNA, proliferating cell nuclear antigen; PIP3, phosphoinositide-3,4,5-triphosphate; Plk1, polo-like kinase 1; PMSA, prostate specific membrane antigen; $\mathrm{pRb}$, retinoblastoma protein; preRC, pre-replicative complex; Rbxl, RING-finger component; SCF, Skp1-Cullin-F-box; TAME, tosyl-L-arginine methyl ester; TGF- $\beta$, transforming growth factor beta; TPR, tetratricopeptide repeat; UPS, ubiquitin proteasome system.
(Acquaviva and Pines, 2006; Hutchins et al., 2010; Kops et al., 2010). However, beyond these similarities regarding adaptors and subunits present in APC/C and SCF ligases, large differences in size and structure exist between these two types of ligases. By contrast to SCF ubiquitin ligases, there is only limited knowledge regarding APC/C structure mainly because the enormous size and complexity of the holoenzyme present significant challenges for structure determination at the atomic level. The first structural insights into the APC/C was obtained by cryo-EM of complexes purified from human cells, Xenopus laevis egg extracts, and budding yeast (Gieffers et al., 2001; Dube et al., 2005; Passmore et al., 2005). 3D modeling showed that in all cases the APC/C is an asymmetric triangular complex ( 200 by $230 \AA$ in size), composed of an outer wall and an internal cavity. Cdh1 and the Cullin domain of the Apc2 subunit are located on the outside of the complex, making it plausible that ubiquitination reactions occur on the outside and not inside the cavity. An emerging view of the APC/C is that of a four-part enzyme composed of a structural arm or scaffolding unit made of Apc1, Apc4, and Apc5, a catalytic arm consisting of Apc2, Apc11, and Doc1 (or Apc10), a tetratricopeptide repeat (TPR) arm made of $\mathrm{Cdc} 23, \mathrm{Cdc16}$, and $\mathrm{Cdc} 27$, which mediates binding to activators and coactivators (Cdc20, Cdh1, Cortex). Other subunits such as Cdc26, Apc9, and Swm1 stabilize the TPR arm (Schwickart et al., 2004; Thornton and Toczyski, 2006). The TPR subunits have 12-15 copies of the 34-amino acid long TPR. They facilitate interactions between subunits and the assembly of multisubunit complexes (Zachariae and Nasmyth, 1999). A pseudo-atomic model of the yeast APC/C obtained by reconstitution studies of the holoenzyme and its subcomplexes has revealed that the TPR arm along with the structural 
arm coordinate the juxtaposition of the catalytic arm and the TPR phosphorylation sites relative to the coactivators, substrates, and regulators (Schreiber et al., 2011).

A previously unidentified APC/C subunit, Apc16, was reported recently (Hutchins et al., 2010; Kops et al., 2010). It is a small protein of $11.7 \mathrm{kDa}$ in size encoded by Chromosome 10 open reading frame 104 (C10orf104) in humans. Apc16 may facilitate Cdc27 hyperphosphorylation, although it is not essential for assembly of the holocomplex (Kops et al., 2010). Therefore, the APC/C is composed of multiple subunits, some of which are newly discovered. However, the minimum ubiquitin ligase module of the $\mathrm{APC} / \mathrm{C}$ that can catalyze ubiquitination is comprised of just two subunits - the Apc2 Cullin subunit and the Apc11 RING subunit (Gmachl et al., 2000; Leverson et al., 2000; Tang et al., 2001), which are analogous to the Cullin and Rbxl subunits of the SCF complex (Barford, 2011). Thus, while we still do not have a complete understanding of $\mathrm{APC} / \mathrm{C}$ structure, we are beginning to understand the general architecture of the complex, and possibly achieve an atomic level resolution of APC/C subcomplexes. These subcomplexes may provide multiple binding sites for small molecules that would perhaps make APC/C unique among ubiquitin ligases as a therapeutic target.

\section{APC/C ACTIVITY}

Another attractive aspect of the APC/C as a drug target is that it binds a unique set of enzymes required for transferring ubiquitin to substrates. The process of ubiquitination begins with the ubiquitin-activating enzyme E1 binding to and activating ubiquitin in an ATP-dependent manner. This activated ubiquitin is then transferred to a ubiquitin-conjugating enzyme or E2. The ubiquitin ligases or E3 enzymes then associate with E2s to catalyze the ubiquitin transfer to the $\varepsilon$-amino group of lysine residues on substrate proteins (Ye and Rape, 2009). Multiple ubiquitin molecules can be linked together in different ways to form polyubiquitin chains that satisfy different objectives. In yeast, chains linked via Lysine 48 of ubiquitin (K48 chains) are a "proteolytic signal" whereas those linked via Lysine 63 (K63 chains) function as molecular scaffolds. In higher eukaryotes, the APC/C is known to build atypical K11-linked polyubiquitin chains on its substrates in association with its unique E2 partner, Ube2C (or UbcH10; Wickliffe et al., 2011b). Ube2C only initiates chain formation, however. Chain elongation is carried out by a K11-specific E2 called Ube2S (or E2-EPF) that works with both APC/C ${ }^{\mathrm{Cdc} 20}$ and APC/C ${ }^{\text {Cdh1 }}$ (Garnett et al., 2009; Wu et al., 2010; Wickliffe et al., 2011a). The importance of this dual regulation of APC/C activity via Ubch10 and Ube2S is underscored by the finding that removing K11-specific E2s causes defects in spindle assembly and mitotic progression (Williamson et al., 2009).

One of the most attractive means of attenuating APC/C activity pharmacologically is by modulating the adaptor protein-substrate binding reaction. Early studies in yeast identified the Cdc20 and Cdh1 substrate binding adaptor proteins as required for APC/C activity (Visintin et al., 1997). Subsequent studies in multiple experimental systems demonstrated the biochemical requirements for these adaptors to bind their substrates (Fang et al., 1998). Although exceptions exist, Cdc20 and Cdh1 bind substrates containing the sequence elements RXXLXXXXN/D/E or destruction boxes (D-boxes), while Cdh1 can also bind substrates containing KEN sequences (Glotzer et al., 1991; Pfleger and Kirschner, 2000). Substrate binding initiates ubiquitination mediated by $\mathrm{APC} / \mathrm{C}^{\mathrm{Cdc2} 2}$ or $\mathrm{APC} / \mathrm{C}^{\mathrm{Cdh} 1}$. However, APC/C $\mathrm{C}^{\mathrm{Cdc} 20}$ or $\mathrm{APC} / \mathrm{C}^{\mathrm{Cdh} 1}$ mediated substrate binding is controlled during the cell cycle using an overlapping series of regulatory mechanisms. Inhibitory complexes control APC/C activity during the cell cycle, thus limiting its activity to defined temporal windows (for reviews see Manchado et al., 2010; Qiao et al., 2010; Pines, 2011). One of the most important examples of this is the exquisite control of $\mathrm{APC} / \mathrm{C}^{\mathrm{Cdc} 20}$ activity during mitosis. In early mitosis, $\mathrm{APC} / \mathrm{C}^{\mathrm{Cdc} 20}$ activity is curtailed by the spindle assembly checkpoint (SAC), which monitors the attachment of kinetochores to the mitotic spindle. An inhibitory complex containing Mad2, Bub3, and BubR1 proteins sequesters Cdc20 and renders it unable to bind substrates (Kim and Yu, 2011). After the checkpoint is switched off, this complex is released from $\mathrm{APC} / \mathrm{C}^{\mathrm{Cdc} 20}$, which initiates the metaphase to anaphase transition by mediating degradation of key proteins such as securin, shugoshin, and cyclin B1 (Kim and Yu, 2011). Securin and cyclin B1 degradation activates separase, which cleaves the cohesin complex that holds sister chromatids together while shugoshin destruction relieves sister chromatid cohesion at the centromere (Wang and Dai, 2005). These reactions are essential for the metaphase to anaphase transition, which is inhibited when APC/C activity is abrogated pharmacologically or by siRNA depletion or genetic disruption of $C d c 20$ (Huang et al., 2009; Manchado et al., 2010; Zeng et al., 2010). Cells lacking APC/C ${ }^{\text {Cdc20 }}$ eventually undergo mitotic catastrophe and die in a manner reminiscent of microtubule inhibition (Zeng et al., 2010). However, APC/C inhibitory molecules may have the added advantage that they will not have the usual off-target effects of microtubule inhibition well-known during chemotherapy treatment (Huang et al., 2009; Manchado et al., 2010).

\section{APC/C ${ }^{\text {Chl } 1}$ CONTROLS SEVERAL CELL CYCLE TRANSITIONS}

Small molecules that inhibit substrate ubiquitination via APC/C $\mathrm{C}^{\mathrm{Cdc20}}$ also reduce APC/C $\mathrm{C}^{\mathrm{Cdh} 1}$ activity (Zeng et al., 2010). Since the APC/ $\mathrm{C}^{\mathrm{Cdh} 1}$ window of activity during the cell cycle is larger than that of $\mathrm{APC} / \mathrm{C}^{\mathrm{Cdc} 20}$, it may be easier to modulate $\mathrm{APC} / \mathrm{C}^{\mathrm{Cdh} 1}$ specific pathways necessary for growth of a particular cancer cell. APC/ $\mathrm{C}^{\mathrm{Cdh} 1}$ controls mitotic exit and maintains the G1-phase in cycling cells (Figure 1). Outside the cell cycle, $\mathrm{APC} / \mathrm{C}^{\mathrm{Cdh} 1}$ is required for quiescence, cell cycle exit, and differentiation (Figure 1). These multiple roles suggest the presence of distinct upstream regulatory and signaling pathways controlling $\mathrm{APC} / \mathrm{C}^{\mathrm{Cdh} 1}$ within temporal or developmental windows. Importantly, these pathways will likely provide unique interactions with $\mathrm{APC} / \mathrm{C}$ that can be targeted pharmacologically.

\section{APC/C ${ }^{\text {Ch1 } 1}$ IS REQUIRED FOR MITOTIC EXIT AND G1 MAINTENANCE}

APC/C $\mathrm{C}^{\mathrm{Cdh} 1}$ targets multiple substrates for degradation during mitosis (Figure 1). Foremost among these are the mitotic cyclins, whose degradation ablates cyclin-dependent kinase 1 (CDK1) activity (Brandeis and Hunt, 1996; Irniger and Nasmyth, 1997). $\mathrm{APC} / \mathrm{C}$ also reduces activity of multiple CDKs by initiating degradation of two components of the SCF ubiquitin ligase, the F-box protein Skp2 and an accessory protein, Cks1 (Bashir et al., 2004; 

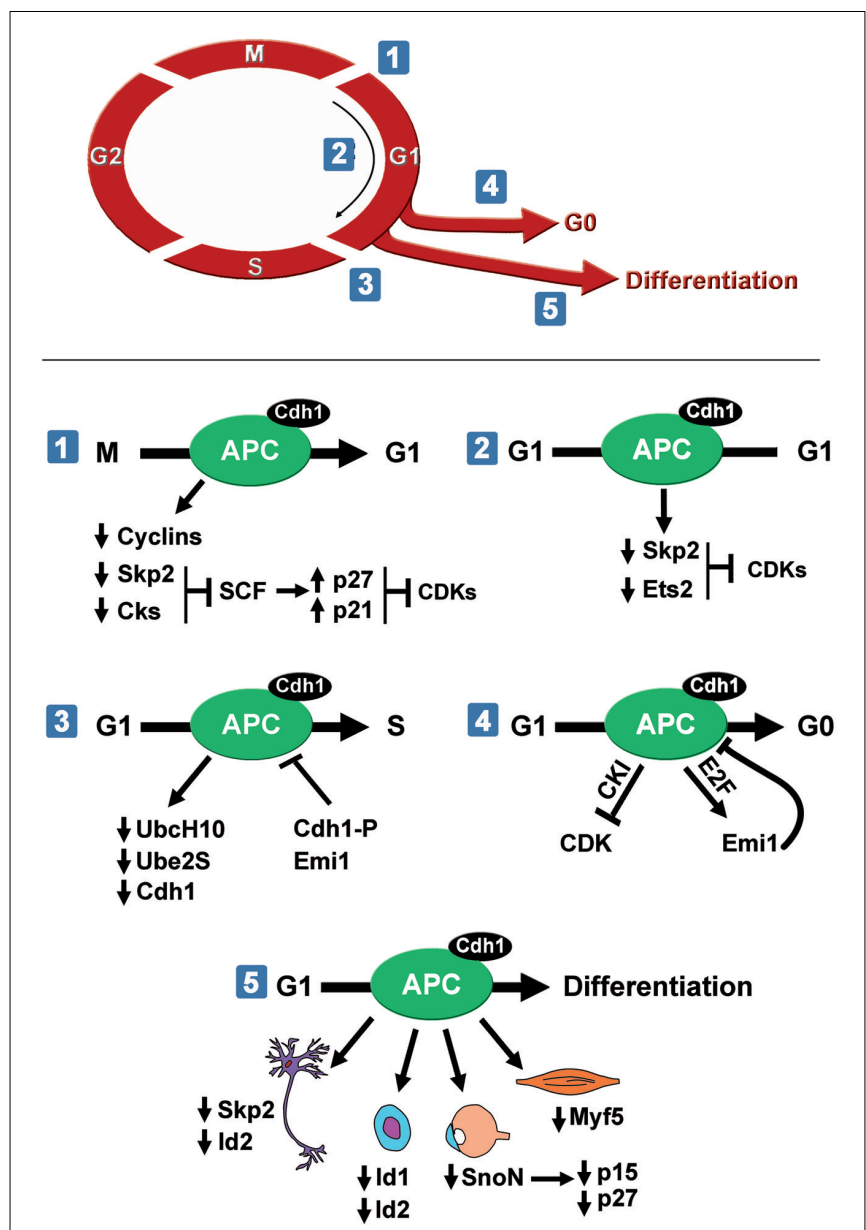

FIGURE 1 | APC/C ${ }^{\text {Cdh1 }}$ regulates several cell cycle phases. $(1,2)$ APC/C ${ }^{\text {Chn } 1}$ promotes mitotic exit and maintains G1-phase by inhibiting CDK activity. (3) $A P C / C^{C d h 1}$ needs to be inactivated for cells to enter $S$ phase. $\mathrm{APC} / \mathrm{C}^{\mathrm{Cah} 1}$ promotes cell cycle exit to a quiescent state (4) or differentiation (5). $A P C / C^{C d h 1}$ induces differentiation of neurons, hematopoietic cells, lens cells, and myocytes.

Wei et al., 2004). Degradation of these two substrates raises the levels of the cyclin-dependent kinase inhibitors p2 ${ }^{\mathrm{Kip} 1}$ and $\mathrm{p} 21^{\mathrm{Cip} 1}$, which are normally targeted for degradation in an $\mathrm{SCF}^{\mathrm{Skp} 2}$ and Cks1 dependent manner (Ganoth et al., 2001; Bornstein et al., 2003). CDK inhibitors associate with specific cyclins and CDKs, preventing them from binding to ATP, and hence blocking their catalytic activity. Thus, high $\mathrm{p} 27^{\mathrm{Kip} 1}$ and $\mathrm{p} 21^{\mathrm{Cip} 1}$ levels maintain an early G1 state by reducing CDK activity. Another mechanism to promote $\mathrm{G} 1$ by reducing $\mathrm{CDK}$ activity involves $\mathrm{APC} / \mathrm{C}^{\mathrm{Cdh} 1}$ mediated inhibition of an activator of $S$ phase entry, cyclin D1. $\mathrm{APC} / \mathrm{C}^{\mathrm{Cdh} 1}$ initiates degradation of the transcription factor Ets2 (Li et al., 2008), which normally controls cyclin D1 levels (Albanese et al., 1995). Consistent with these findings, depletion of Cdh1 by siRNA stabilizes Skp2 and Ets2, resulting in p2 $1^{\mathrm{Cip} 1}$ and $\mathrm{p} 27^{\mathrm{Kip} 1}$ degradation and cyclin D1 elevation in G1, followed by premature S phase entry (Wei et al., 2004; Li et al., 2008) and increased proliferation (Bashir et al., 2004). Thus, APC/C $\mathrm{C}^{\mathrm{Cdh} 1}$ function during mitotic exit is coupled to G1 maintenance. It initiates a sharp decrease in CDK1 activity during mitotic exit by targeting the mitotic cyclins for destruction and subsequently remains active in early G1 to ensure that they remain inactive. In addition, it ensures that other cyclin-dependent kinases, namely CDK2/cyclin E, CDK2/cyclin A, CDK4/cyclin D, and CDK6/cyclin D are inactive since it maintains high $\mathrm{p} 27^{\mathrm{Kip} 1}$ levels and low cyclin D1 levels through Skp2 and Ets2 degradation.

One question that immediately arises from these studies is that if APC/C keeps CDKs inactive in early G1, how do cells eventually reach $S$ phase. The answer lies in the multiple mechanisms that decrease APC activity (Figure 1). For instance, the ubiquitination of the APC/C-specific ubiquitin-conjugating enzyme (E2) $\mathrm{UbcH} 10$ by $\mathrm{APC} / \mathrm{C}^{\mathrm{Cdh} 1}$ provides a negative feedback mechanism that eventually dampens APC/ $\mathrm{C}^{\mathrm{Cdh} 1}$ activity (Rape and Kirschner, 2004; Rape et al., 2006). Further, Cdh1 is inactivated by both phosphorylation and degradation (Lukas et al., 1999; Listovsky et al., 2004; Benmaamar and Pagano, 2005). Finally, E2F activates the transcription of the APC/C pseudo-substrate early mitotic inhibitor-1 (Emi1)/Rcal in late G1, which inhibits $A P C / C^{C d h 1}$ activity (Hsu et al., 2002). These distinct mechanisms ensure that APC/C ${ }^{\text {Cdh } 1}$ activity remains low from late G1 until the subsequent metaphase when it is activated via reduction of CDK and Emil activity (Kotani et al., 1998; Hsu et al., 2002; Figure 1).

\section{APC/C ${ }^{\text {Chn } 1}$ CONTROLS PRE-REPLICATION COMPLEX FORMATION}

One of the main reasons $\mathrm{APC} / \mathrm{C}^{\mathrm{Cdh} 1}$ activity must remain low during $S$ phase is that it is an inhibitor of pre-replication complex formation required for S phase entry (Diffley, 2004). APC/C Cdh1 controls the formation of the pre-replication complexes by modulating levels of three major regulators of the formation of the complex: Orc1, Cdc6, and geminin. For DNA replication to proceed, cells need to alternate between periods of low CDK activity and low geminin levels, in which the pre-replicative complexes (preRCs) are assembled; and periods of high CDK activity and high geminin levels in which origin firing and DNA replication occurs (McGarry and Kirschner, 1998; Petersen et al., 2000; Araki et al., 2003). APC/ $\mathrm{C}^{\mathrm{Cdh} 1}$ is crucial to properly regulate the switch between these two states. For instance, Orcl and Cdc6 are degraded via APC/C $\mathrm{C}^{\mathrm{Cdh} 1}$ during early G1 (Petersen et al., 2000; Araki et al., 2003). Further, geminin levels are tightly controlled by APC/C ${ }^{\mathrm{Cdh} 1}$. Geminin prohibits initiation of DNA replication at inappropriate times of the cell cycle by preventing MCM recruitment at the replication origins. During G1 the APC/C is active and as a consequence, geminin concentration is low. At the G1-S transition, APC/C is inactivated and geminin begins to accumulate. However, geminin concentration is not sufficient to inhibit a first wave of preRC formation and DNA replication begins. As S phase progresses, geminin accumulates and inhibits subsequent recruitment of MCMs to the replication origins (McGarry and Kirschner, 1998), and therefore re-duplication is avoided (McGarry and Kirschner, 1998; Wohlschlegel et al., 2000).

\section{APC/C ${ }^{\text {dh1 } 1}$ PROMOTES CELL CYCLE EXIT AND QUIESCENCE}

Multiple studies suggest that a major APC/ $\mathrm{C}^{\mathrm{Cdh} 1}$ function outside of the cell cycle is limiting CDK activity required for cell cycle progression (Qiao et al., 2010). APC/C $\mathrm{C}^{\mathrm{Cdh} 1}$ regulates CDK inhibitors that reduce $\mathrm{CDK}$ activity and initiate cell cycle exit. Adding a 
second layer of regulation to $\mathrm{APC} / \mathrm{C}^{\mathrm{Cdh} 1}$ activity, Binné et al. (2007) connected retinoblastoma protein ( $\mathrm{pRb})$ to $\mathrm{APC} / \mathrm{C}^{\mathrm{Cdh} 1}$, Skp2, and CDK inhibitor dependent cell cycle exit. These studies demonstrated that hypophosphorylated $\mathrm{pRb}$ associates with the APC/C specifically when activated by Cdh1, thus promoting Skp 2 degradation and accumulation of $\mathrm{p} 27^{\mathrm{Kip} 1}$ and $\mathrm{p} 21^{\mathrm{Cip} 1}$. This important finding linked extracellular signaling mechanisms, which normally control pRb activity to APC/C dependent degradation of Skp2 and initiation of cell cycle exit.

Once cells have exited the cell cycle, APC/C activity is required to maintain quiescence or differentiation. For instance, APC ${ }^{\text {Cdh1 }}$ inactivation by deleting its Apc2 subunit in adult hepatocytes induced these otherwise quiescent cells to re-enter the cell cycle (Wirth et al., 2004). Similarly, APC ${ }^{\text {Cdh1 }}$ has also been proposed to block postmitotic differentiated neurons from inappropriate cycling and apoptosis (Almeida et al., 2005; Jackson, 2006).

\section{APC/C ${ }^{\text {Cdh1 }}$ REGULATES CELL CYCLE EXIT AND CELL DIFFERENTIATION}

$\mathrm{APC} / \mathrm{C}^{\mathrm{Cdh} 1}$ activity promotes cell cycle exit and differentiation since Cdh1 depletion reduces differentiation of muscle, lens, hematopoietic, and neuronal cells (Lasorella and Iavarone, 2006; Li et al., 2007; Wu et al., 2007; Garcia-Higuera et al., 2008). Although our knowledge of the involvement of $\mathrm{APC} / \mathrm{C}^{\mathrm{Cdh} 1}$ in the differentiation of other tissues awaits further investigation, its critical function in the degradation of cell cycle proteins suggests it likely plays relevant roles in linking quiescence and differentiation in most cell types. Further, since cancer progression is often thought to involve a dedifferentiation process (Daley, 2008; Trosko, 2009), understanding APC/C's involvement in normal cell cycle exit and differentiation will give us clues as to how APC/C regulation or substrate targeting may be misregulated during tumorigenesis.

\section{Neuronal differentiation}

Following a period of proliferation, neural progenitors differentiate into postmitotic neurons. Since Cdh1 levels are (Gieffers et al., 1999; Stegmuller and Bonni, 2005) higher in postmitotic neurons relative to their neural progenitors (Yao et al., 2010), APC/C $\mathrm{C}^{\mathrm{Cdh} 1}$ may play a role in neuronal cell cycle exit. Consistent with this notion, an increase in $\mathrm{APC} / \mathrm{C}^{\mathrm{Cdh} 1}$ activity and a decrease of $\mathrm{APC} / \mathrm{C}^{\mathrm{Cdh} 1}$ substrates has been observed during terminal differentiation (Almeida et al., 2005; Yao et al., 2010). By contrast, upregulation of APC/C ${ }^{\mathrm{Cdh} 1}$ substrates has been described in human neural tumors, suggesting that $\mathrm{APC} / \mathrm{C}^{\mathrm{Cdh} 1}$ activity is attenuated under these conditions (Lasorella and Iavarone, 2006; Eckerle et al., 2009).

\section{Inhibitor of DNA binding 2}

One of the targets that couples APC/C $\mathrm{C}^{\mathrm{Cdh} 1}$ activity with neuronal differentiation is inhibitor of DNA binding 2 (Id2, also known as inhibitor of differentiation 2). In the developing nervous system, Id 2 has been shown to inhibit the activity of neurogenic basic helix-loop-helix (bHLH) transcription factors required for neuronal differentiation (Yokota, 2001; Perk et al., 2005; Rothschild et al., 2006; Jung et al., 2010). APC/C ${ }^{\text {Cdh1 }}$ targets Id2 for destruction, which couples cell cycle exit, differentiation, and axonal growth during the differentiation of diverse neuronal types (Lasorella and Iavarone, 2006; Yao et al., 2010). Thus, Id2 protein downregulation via proteolysis is essential for neuronal differentiation, suggesting that deregulation of Id 2 destruction may underlie neural tumors.

Deregulated Id 2 expression prevents cell cycle arrest via a wide range of signals (Lasorella et al., 2002; Kowanetz et al., 2004; Baghdoyan et al., 2005). Id 2 downregulation via degradation allows the bHLH transcription factor E47 levels to increase and subsequently promote neural cell differentiation through induction of the CDK inhibitor $\mathrm{p} 57^{\mathrm{Kip} 2}$ in the developing mouse brain (Rothschild et al., 2006; Tury et al., 2011). Similarly, decreasing Id2 levels increases expression of known mediators of neuronal differentiation such as Hes1 and Ascl1 (Mash1) transcription factors (Havrda et al., 2008) and NeuroD/E47 (Jung et al., 2010). Under certain experimental conditions, ectopic Id 2 is able to drive terminally differentiated cells back into the cell cycle (Chaudhary et al., 2005). Importantly, the observation that the most aggressive tumors frequently contain the highest levels of Id proteins raises the possibility that deregulating Id protein stability by $\mathrm{APC} / \mathrm{C}^{\mathrm{Cdh} 1}$ might also contribute to Id accumulation in cancer.

\section{Skp2}

The APC/C substrate Skp2 controls the G1 to S transition by eliminating numerous regulatory proteins that inhibit $S$ phase entry (Reed, 2008). The SCF ${ }^{\text {Skp2 }}$ target $\mathrm{p} 27^{\mathrm{Kip} 1}$ plays a large role in cell cycle exit and differentiation, particularly neuronal differentiation (Durand et al., 1998; Vernon et al., 2003; Tarui et al., 2005; Nguyen et al., 2006, 2007). Genetic disruption of $p 27^{K i p 1}$ causes a general increase in cell proliferation (Fero et al., 1996; Carruthers et al., 2003), including neurogenesis in the cortex and spinal cord (Nguyen et al., 2007; Li et al., 2009). Control of p27 ${ }^{\text {Kip1 }}$ is dual, subject to the accumulation of both cyclin-CDK complexes, which promote its phosphorylation, and Skp2, which promote the ubiquitination of phosphorylated p27 Kip1 (Carrano et al., 1999; Montagnoli et al., 1999). Harmey et al. (2009) described an essential role for $\mathrm{APC} / \mathrm{C}^{\mathrm{Cdh} 1}$ in cerebellar granule progenitors by mediating Skp2 destruction, thus coordinating cell cycle exit and terminal differentiation. Similar studies uncovered APC/C ${ }^{\text {Cdh1 }}-S k p 2$ dependent differentiation of human embryonic stem cells (Bar-On et al., 2010). Collectively, these data suggested that two well-known inducers of neuronal differentiation, nerve growth factor (NGF), and retinoic acid, hyperactivate $\mathrm{APC} / \mathrm{C}^{\mathrm{Cdh} 1}$. NGF rapidly induced $\mathrm{APC} / \mathrm{C}^{\mathrm{Cdh} 1}$ activity and promoted degradation of APC substrates, including cyclin B1 and the F-box protein Skp2 (Harmey et al., 2009). Similarly, retinoic acid promoted neuronal differentiation through increasing APC/C ${ }^{\text {Cdh1 } 1}$ activity (Cuende et al., 2008; Yao et al., 2010). Further, retinoic acid induced nuclear accumulation of Cdh1, enhancing APC/C $\mathrm{C}^{\mathrm{Cdh} 1}$ activity, Skp2 destabilization, and p27 ${ }^{\mathrm{Kip} 1}$ accumulation (Cuende et al., 2008) by reducing expression of Rae1, a nuclear export factor that limits APC/C ${ }^{\text {Cdh1 }}$ activity in mitosis (Yao et al., 2010). Similar to NGF and retinoic acid, bone morphogenetic protein 2 (BMP2) promotes cell cycle arrest via downregulation of Skp2 and accumulation of p27 Kip1 in a neuroblastoma cell line (Nakamura et al., 2003). Thus, Skp2 degradation via $\mathrm{APC} / \mathrm{C}^{\mathrm{Cdh} 1}$ is linked to neuronal differentiation and various signaling pathways. Disruption of signaling pathways controlling the APC/C-Skp2 axis during neuronal differentiation may lead to disruption of homeostasis. Consistent with this 
possibility, reduced Skp2 and cyclin B1 expression has been seen in a transgenic model of Down syndrome where alteration of cell cycle rate and reduction of neurogenesis in the cerebellum was described (Contestabile et al., 2009). Moreover, Skp2 transcript levels gradually increase with the aggressiveness of neuroblastoma subtype (Westermann et al., 2007), making the regulation of Skp2 by $\mathrm{APC} / \mathrm{C}^{\mathrm{Cdh} 1}$ an attractive target in tumorigenesis.

\section{Muscle cell differentiation}

Myogenesis is a multistep process that sequentially requires the proliferation of committed myoblasts, the differentiation of myoblasts into postmitotic myocytes, and finally fusion of myocytes to form a multinucleated myotube with contractile capability. In muscle, APC/ $\mathrm{C}^{\mathrm{Cdh} 1}$ drives cell differentiation through the destruction of two proteins, Skp2 and Myf5 (Li et al., 2007; Figure 1). Elimination of Skp2 leads to the accumulation of the CDK inhibitors $\mathrm{p} 21^{\mathrm{Cip} 1}$ and $\mathrm{p} 27^{\mathrm{Kip} 1}$ in myoblasts, allowing cell cycle withdrawal. Consistent with a role of $\mathrm{p} 21^{\mathrm{Cip} 1}$ in myotube formation, mice lacking $\mathrm{p} 21^{\mathrm{Cip} 1}$ fail to form myotubes (Zhang et al., 1999). Thus, the APC/C-Skp2-p21 Cip1/p27 Kip1 axis is likely to be essential for muscle development.

Coupled to APC/C mediated destruction of Skp2 in muscle is APC/C targeting of Myf5. Myf5 is a bHLH transcription factor that regulates myoblast proliferation and homeostasis (GayraudMorel et al., 2007). Its expression is restricted to dividing and undifferentiated cells. Myf5 is not directly involved in the decision to differentiate per se but in Myf5 null animals, differentiation is delayed during early regeneration and Myf5 null mutants are characterized by a subtle progressive myopathy and muscle regeneration deficits (Gayraud-Morel et al., 2007). Degradation of Myf5 by APC/C $\mathrm{C}^{\mathrm{Cdh} 1}$ facilitates myogenic fusion, a process required for myoblast differentiation (Gayraud-Morel et al., 2007). Importantly, impaired degradation of both Skp2 and Myf5 seems to have a role in muscle cancer since overexpression of Skp2 and Myf5 are found in cervical carcinoma and rhabdomyosarcomas, respectively (Tamamori-Adachi et al., 2004; Zibat et al., 2010).

\section{Lens cell differentiation}

Proper lens differentiation requires precise temporal control of the cell cycle and the coordination of cell cycle exit with differentiation cues and signaling pathways (Zhu and Skoultchi, 2001). $\mathrm{APC} / \mathrm{C}^{\mathrm{Cdh} 1}$ has been identified as a crucial regulator of lens differentiation that induces SnoN degradation (Wu et al., 2007). SnoN, a critical transcriptional corepressor of the TGF- $\beta$ pathway, has been proposed to be a functional switch controlling the expression of p15 and p $21^{\mathrm{Cip} 1}$ (Zhu et al., 2005). p $21^{\mathrm{Cip} 1}$ and p15 are two essential cell cycle inhibitors that contribute to cell cycle arrest via downregulation of cyclin D/CDK4/6 activity (Reynisdottir et al., 1995). The upregulation of the $\mathrm{p} 21^{\mathrm{Cip} 1}$ and p15 inhibitors is necessary for coupling cell cycle withdrawal in response to TGF- $\beta$ signaling and the initiation of lens differentiation. Moreover, $C d h 1$ depletion was shown to attenuate induction of p 15 and $\mathrm{p} 21^{\mathrm{Cip} 1}$ and significantly block lens differentiation (Wu et al., 2007). Impaired regulation of SnoN has not been related to corneal tumors but given the importance of $\mathrm{APC} / \mathrm{C}^{\mathrm{Cdh} 1}$ in lens differentiation, further studies could open new potential targets in these carcinomas.

\section{Hematopoietic cell differentiation}

Hematopoiesis gives rise to all blood cells through a complex series of proliferation and differentiation events that occur throughout lifespan (Kawamoto et al., 2010). The hematopoietic system consists of a large array of differentiated blood cells including erythrocytes and cells of the myeloid and lymphoid lineages. Evidence supporting a role for $\mathrm{APC} / \mathrm{C}^{\mathrm{Cdh} 1}$ in hematopoiesis comes from Cdh 1 knockout mice. Cdh1 heterozygous mice develop B-cell lymphoma and myelodysplastic disorder (Garcia-Higuera et al., 2008). Although how APC/C ${ }^{\mathrm{Cdh} 1}$ regulates hematopoiesis remains to be investigated, targeted degradation of Id protein could be one mechanism (Figure 1). While Id proteins are downregulated during cell cycle exit, overexpression of Id proteins in terminally differentiated cells triggers cell cycle re-entry. Id proteins modulate cellular proliferation and differentiation in hematopoietic cells (Perk et al., 2005). Id1 is essential for hematopoietic stem cell maintenance and hematopoietic development (Perry et al., 2007) and the balance between Id1 and E-protein regulates myeloidversus-lymphoid lineage commitment (Cochrane et al., 2009). Dysfunction of $I d 2$ in mice or cultured cells induces lymphoid differentiation, whereas Id2 overexpression inhibits lymphoid and myeloid differentiation (Perk et al., 2005; Ji et al., 2008). Furthermore, in addition to an Id 1 and Id 2 requirement for the proliferation and differentiation of hematopoietic precursors, these factors may contribute to the development of myeloid malignancies through enhanced proliferation or inhibited differentiation (Perk et al., 2005).

\section{APC/C ${ }^{\text {Cdh1 } 1}$ PRESERVES CHROMOSOME INTEGRITY}

Loss of Cdh1 function produces precocious initiation of DNA synthesis, leading to lower $S$ phase progression, which results in stalled replication forks and under-replicated DNA (GarciaHiguera et al., 2008). These replicative defects, as well as the upregulation of mitotic kinases, can ultimately lead to genetic damage (Garcia-Higuera et al., 2008; Cotto-Rios et al., 2011). Cdh1-deficient cells exhibit defects in mitotic exit and cytokinesis and accumulate a variety of genomic aberrations (Engelbert et al., 2008; Garcia-Higuera et al., 2008). Such genomic aberrations may be a consequence of the inability of $\mathrm{APC} / \mathrm{C}^{\mathrm{Cdh} 1}$ to properly mediate a response to DNA damage in Cdh1 null cells. In G1, $\mathrm{APC} / \mathrm{C}^{\mathrm{Cdh} 1}$ targets the ubiquitin specific protease USP1 for proteasome dependent degradation (Cotto-Rios et al., 2011). Since USP 1 counteracts monoubiquitination of the DNA repair protein proliferating cell nuclear antigen (PCNA), APC/C ${ }^{\mathrm{Cdh} 1}$ dependent USP1 destruction allows a permissive environment during $\mathrm{G} 1$ for PCNA monoubiquitination, which is required for UV-mediated DNA gap repair (Cotto-Rios et al., 2011). In addition to USP1, APC/C ${ }^{\text {Cdh1 } 1}$ controls the levels of multiple proteins involved in the DNA damage checkpoint response and DNA repair including Claspin, Rad17, thymidine kinase 1, and the ribonucleotide reductase subunit (Chabes et al., 2003; Ke et al., 2005; Bassermann et al., 2008; Gao et al., 2009a; Zhang et al., 2010). During G2, the APC/ $\mathrm{C}^{\mathrm{Cdh} 1}$ substrate polo-kinase 1 (Plk1) controls CDK1 activation and recovery from DNA replication stresses (Watanabe et al., 
2004; Mamely et al., 2006). Cells exposed to genotoxic stress in G2 need to arrest the cell cycle and repair damaged DNA. One mechanism to achieve this is to reduce levels of proteins such as Plk1 and mitotic cyclins, which are required for mitotic entry. Although normally inactive during $\mathrm{G} 2, \mathrm{APC} / \mathrm{C}^{\mathrm{Cdh} 1}$ is activated via $\mathrm{Cdh} 1$ dephosphorylation during genotoxic stress, which is mediated by the Cdc14B phosphatase (Bassermann et al., 2008). Therefore, participation of $\mathrm{APC} / \mathrm{C}^{\mathrm{Cdh} 1}$ in the G2 DNA damage response suggests another mechanism for genomic instability observed in $C d h 1$ null cells.

\section{APC/C ${ }^{\text {Chl1 } 1}$ MODULATORS AS TUMOR SUPPRESSOR PROTEINS OR ONCOGENES}

Considering the prominent role of $\mathrm{APC} / \mathrm{C}$ in cell cycle regulation and genomic stability, it is tempting to speculate that its dysregulation triggers a major perturbation of cell cycle progression and contributes to cell transformation. In fact, hemizygous frameshift and point mutations in several subunits of APC/C have been found in colon cancer cell lines and tumors (Wang et al., 2003). Mutations in Apc3, Apc6, and Apc8 were found in colon cancer, breast cancer, neuroblastoma, hepatocarcinoma, melanoma, glioma, choriocarcinoma, endometrial cancer, ovarian cancer, and prostate carcinoma (Wang et al., 2003). Overexpression studies of Apc8 suggested that APC/C mutations can act in a dominant-negative manner to inhibit its function and cause inappropriate cell cycle progression (Wang et al., 2003). Moreover, the APC/C cofactor Cdh1 has been described as a tumor suppressor (Garcia-Higuera et al., 2008). Knockdown or inhibition of Cdh1 is associated with centrosome amplification and chromosome mis-segregation, and is implicated in genomic instability and tumorigenesis (Ross and Cohen-Fix, 2003; Wasch and Engelbert, 2005; Engelbert et al., 2008; Garcia-Higuera et al., 2008). Cdh1deficient mice display genomic instability and heterozygous $C d h 1$ mice develop epithelial tumors, such as mammary gland adenocarcinomas and fibroadenomas, which are not observed in wild-type mice. Furthermore, these tumors contain one Cdh1 wild-type allele, suggesting that $C d h 1$ is haploinsufficient for tumor suppression. In addition to mutations in APC/C or Cdh1 subunits, it is tempting to speculate that alterations of $\mathrm{APC} / \mathrm{C}$ upstream regulators may lead to transformation (Table $\mathbf{1}$ ).

\section{RETINOBLASTOMA PROTEIN}

A well-established tumor suppressor protein that positively regulates APC/C activity is the $\mathrm{pRB}$. pRB plays multiple roles during the cell cycle; it blocks cell cycle progression from G1 to S phase, and guards the cell from replicating damaged DNA, thus preventing the integration of mutations into the genome. This tumor suppressor function requires binding and repressing the E2F family transcription factors (Classon and Harlow, 2002; Chen et al., 2009). Reversion of the $\mathrm{pRb}-\mathrm{E} 2 \mathrm{~F}$ interaction occurs after mitogenic stimuli sufficient for the activation of CDKs that phosphorylate $\mathrm{pRB}$ in the nucleus. Subsequently, phospho-pRb is released from E2Fs, which can then induce S phase entry (Thoma et al., 2011). Consistent with a direct inhibitory role in S phase entry, loss of various pRBs leads to unscheduled cell proliferation in many tissues (Vidal and Koff, 2000; Cobrinik, 2005; Marx et al., 2010). Accordingly, mutations in $R b$ are found in a wide variety of cancers mainly in the lung, breast, and eye (Meraldi et al., 1999; Sabado Alvarez, 2008).

Retinoblastoma protein also possesses E2F-independent functions that contribute to cell cycle control. pRB interacts with both Skp2 (Ji et al., 2004) and with APC/C ${ }^{\text {Cdh1 }}$ through distinct surfaces (Binné et al., 2007). pRB needs to interact with both proteins to target Skp2 for ubiquitin-mediated degradation and promote p2 $7^{\mathrm{Kip} 1}$ accumulation and cell cycle exit. Interestingly, similar to E2F1, Cdh1 only interacts with the hypophosphorylated (active) form of $\mathrm{pRb}$, and phosphorylation of $\mathrm{pRb}$ by cyclin A/CDK2 kinase abolished the ability of $\mathrm{Rb}$ to interact with both $\mathrm{Cdh} 1$ and E2F1. Therefore Cdh1, by competing with pRb interaction, can also regulate the activity of the E2F1 transcription factor (Sorensen et al., 2000; Gao et al., 2009a). Further, given that both $\mathrm{pRB}$ and Cdh1 have tumor suppressive functions, whether the $\mathrm{pRB}-\mathrm{APC} / \mathrm{C}^{\mathrm{Cdh} 1}$ interaction is misregulated during tumorigenesis should be investigated (Figure 2).

\section{PTEN}

Recent studies have demonstrated that the well-characterized tumor suppressor protein PTEN is a positive regulator of APC/C activity. PTEN (Cairns et al., 1997; Steck et al., 1997; Feilotter et al., 1998; Gray et al., 1998; Li and Sun, 1998) encodes a lipid phosphatase, which plays a crucial role in adhesion, migration, growth, and apoptosis. Pten-null mice die embryonically, but heterozygous mice survive and develop tumors in the lymphoid system, endometrium, prostate, and the thyroid (Di Cristofano et al., 1998; Podsypanina et al., 1999). Pten somatic mutations occur in a large percentage of human cancers, with the highest numbers found in endometrial, central nervous system, skin, and prostate cancers (Chalhoub and Baker, 2009).

The effects observed after PTEN loss have been attributed to activation of the PI3K/AKT pathway as PTEN can dephosphorylate phosphoinositide-3,4,5-triphosphate (PIP3), a potent activator of Aktl (Maehama and Dixon, 1998). PTEN inactivation by phosphorylation or oxidation in human cancer results in elevated Akt1 activity and abnormal growth regulation (Silva et al., 2008; Chalhoub and Baker, 2009; McCubrey et al., 2011). However, functions independent of its phosphatase activity have been described (Maier et al., 1999; Georgescu et al., 2000; Koul et al., 2002a,b; Gildea et al., 2004; Blanco-Aparicio et al., 2007). Recently, a novel interaction between PTEN and $\mathrm{APC} / \mathrm{C}^{\mathrm{Cdh} 1}$ has been reported (Song et al., 2011). Song et al. (2011) demonstrated that nuclear PTEN directly enhances the activity of APC/C by promoting its association with $\mathrm{Cdh} 1$ in a phosphatase-independent manner. Conversely, PTEN loss impairs the activity of the APC/C $\mathrm{C}^{\mathrm{Cdh} 1} \mathrm{com}-$ plex. Therefore, loss of PTEN function decreases APC/C $\mathrm{Cdh}^{\mathrm{Cd} 1}$ activity, suggesting novel molecular pathways that may be involved in the progression and initiation of tumorigenesis. This in turn highlights the complexity of the dose-dependent tumor promoting and fail-safe cellular responses evoked by PTEN loss. Accordingly, tumor-derived mutations that do not affect the phosphatase enzymatic activity of PTEN in vitro have also been identified. These were found to affect the compartmentalization of PTEN in the cell, either by sequestering PTEN in the nucleus (Denning et al., 2007) or by interfering with PTEN's recruitment to the plasma membrane (Lee et al., 1999; Georgescu et al., 2000; Walker et al., 
Table 1 | Modulators of APC/C ${ }^{\mathrm{Cdh} 1}$ dysregulated in cancer.

\begin{tabular}{|c|c|c|c|c|c|}
\hline $\begin{array}{l}\mathrm{APC} / \mathrm{C} \\
\text { regulator }\end{array}$ & Effects on APC/C & $\begin{array}{l}\text { Major cell } \\
\text { cycle function (s) }\end{array}$ & Role in tumorigenesis & Relevant cancers & Relevant reference \\
\hline PTEN & $\begin{array}{l}\text { Activator. Promotes the } \\
\text { interaction between } \\
\text { APC/C and Cdh1 }\end{array}$ & $\begin{array}{l}\text { Promotes cell } \\
\text { differentiation. } \\
\text { Downregulation } \\
\text { promotes cell } \\
\text { proliferation }\end{array}$ & $\begin{array}{l}\text { Acts as a tumor } \\
\text { suppressor. Null mice die } \\
\text { and heterozygous develop } \\
\text { tumors }\end{array}$ & $\begin{array}{l}\text { Lymphoid system, } \\
\text { endometrium, thyroids, } \\
\text { central nervous system, } \\
\text { skin, prostate, breast }\end{array}$ & $\begin{array}{l}\text { Chalhoub et al. (2009), } \\
\text { Hollander et al. (2011), } \\
\text { Song et al. (2011), Uddin } \\
\text { et al. (2004), Kwon et al. } \\
\text { (2008) }\end{array}$ \\
\hline Sirt2 & $\begin{array}{l}\text { Activator. Acetylates } \\
\text { Cdh1 and Cdc20 } \\
\text { promoting their } \\
\text { interaction with APC/C }\end{array}$ & $\begin{array}{l}\text { Regulates } \\
\text { chromosomal } \\
\text { condensation during } \\
\text { mitosis. Maintains } \\
\text { genome integrity }\end{array}$ & $\begin{array}{l}\text { Acts as a tumor } \\
\text { suppressor. Decrease of } \\
\text { function promotes } \\
\text { genome instability }\end{array}$ & $\begin{array}{l}\text { Breast, liver, brain, } \\
\text { kidney, and prostate } \\
\text { cancers }\end{array}$ & $\begin{array}{l}\text { North and Verdin (2007), } \\
\text { Kim et al. (2011) }\end{array}$ \\
\hline PSMA & $\begin{array}{l}\text { Activator. Associates } \\
\text { with } \mathrm{Cdc} 27\end{array}$ & Unknown & $\begin{array}{l}\text { Acts as an oncogene. } \\
\text { Overexpression promotes } \\
\text { premature activation of } \\
\text { APC/C and aneuploidy }\end{array}$ & Prostate cancer & $\begin{array}{l}\text { Rajasekaran et al. } \\
\text { (2005, 2008), Burger } \\
\text { et al. (2002), Chang } \\
\text { et al. }(1999,2001)\end{array}$ \\
\hline Emi1 & $\begin{array}{l}\text { Inhibitor. Binds to } \\
\text { APC/C }\end{array}$ & $\begin{array}{l}\text { Permits accumulation } \\
\text { of cyclins in } \mathrm{G} 1 / \mathrm{S}\end{array}$ & $\begin{array}{l}\text { Overexpression with p53 } \\
\text { knock down promotes } \\
\text { proliferation and } \\
\text { chromosomal instability }\end{array}$ & $\begin{array}{l}\text { Kidney, liver, lung, } \\
\text { endometrium, lymphoid } \\
\text { system, ovarium, lung }\end{array}$ & $\begin{array}{l}\text { Hsu et al. (2002), Miller } \\
\text { et al. (2006), Lehman } \\
\text { et al. (2006), Gütge- } \\
\text { mann et al. (2008) }\end{array}$ \\
\hline MAK & $\begin{array}{l}\text { Inhibitor. } \\
\text { Phosphorylates Cdh1 }\end{array}$ & $\begin{array}{l}\text { Promotes stabilization } \\
\text { of } A P C / C^{C d h 1} \\
\text { substrates }\end{array}$ & $\begin{array}{l}\text { Acts as an oncogene. } \\
\text { Overexpression promotes } \\
\text { extra-centrosomes }\end{array}$ & Prostate cancer & Wang and Kung (2011) \\
\hline
\end{tabular}

of $\mathrm{APC} / \mathrm{C}^{\mathrm{Cdh}}$

substrates
Overexpression promotes extra-centrosomes
Breast, liver, brain,

kidney, and prostate

cancers

Kidney, liver, lung, endometrium, lymphoid

Prostate cancer

\section{(2005, 2008), Burger et al. (2002), Chang et al. $(1999,2001)$ \\ Hsu et al. (2002), Miller et al. (2006), Lehman et al. (2006), Gütge- mann et al. (2008)}

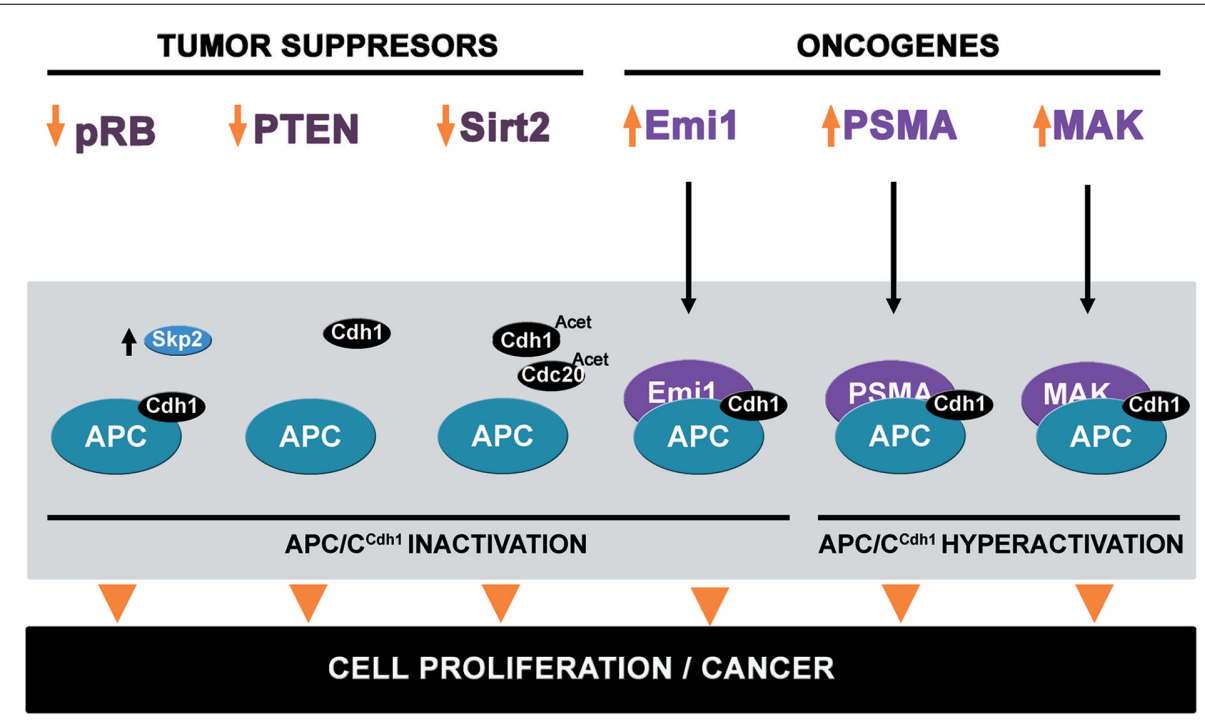

FIGURE 2 | Dysregulation of APC/ $\mathrm{C}^{\mathrm{cdh} 1}$ modulators can promote cancer. Decreasing expression of the tumor suppressors pRB, PTEN, and Sirt2 may promote $A P C / C^{C d n} 1$ inactivation, leading to cell proliferation and tumorigenesis. pRB downregulation may decrease Skp2 destruction. Decreasing PTEN levels might reduce APC/C activity. Decrease of Sirt2 could enhance the acetylation of the coactivators Cdh1 and Cdc20, lowering the capacity to interact with APC/C. In addition to the tumor suppressors, the oncogenes Emi1, PSMA, and MAK also regulate APC/C Chh1 activity. Emi1 binds as a pseudo-substrate and leads to APC/C inactivation. PSMA and MAK increase APC/C Cah1 activity and produce genomic instability. 
2004), thus possibly negatively impacting the PTEN-APC/C Cdh1 interaction. Consistent with this possibility, $\mathrm{APC} / \mathrm{C}^{\mathrm{Cdh} 1}$ substrates are overexpressed in tumors containing PTEN deficiency (Marino et al., 2002; Gao et al., 2009a; Liu et al., 2011b). Further, PTEN overexpression has been found to suppress tumorigenesis by inducing G1 cell cycle arrest in human glioblastoma cells (Li and Sun, 1998). Given the importance of PTEN and $\mathrm{APC} / \mathrm{C}^{\mathrm{Cdh} 1}$ for cancer progression, it will be crucial to determine whether tumors containing PTEN misregulation have both hyeractivation of the Akt1 pathway and dysregulation of $\mathrm{APC} / \mathrm{C}^{\mathrm{Cdh} 1}$ function (Figure 2).

\section{EARLY MITOTIC INHIBITOR-1}

The Emil is an APC/C inhibitor, which is overexpressed in multiple tumors. Emil is a key cell cycle regulator that is required for accumulation of mitotic cyclins and other critical cell cycle regulators during S phase and G2 (Hsu et al., 2002). At the G1/S transition, Emil functions as a pseudo-substrate inhibitor of the APC/C (Miller et al., 2006), allowing substrates to accumulate (Guardavaccaro et al., 2003; Miller et al., 2006). In early mitosis, Emil is phosphorylated by Plk1 (Hansen et al., 2004), which triggers $\mathrm{SCF}^{\beta \mathrm{TrCP}}$-dependent ubiquitination and destruction, thus inducing APC/C activation and mitotic progression (MargottinGoguet et al., 2003). Emil overexpression leads to unscheduled cell proliferation, tetraploidy, and chromosomal instability in $p 53$ deficient cells (Lehman et al., 2006; Figure 2). In p53 wild-type cells, the induction of tetraploidy and aneuploidy by overexpressing APC/C inhibitors like Emil typically leads to G1 arrest or apoptosis. Indeed, Emil overexpression causes mitotic catastrophe and genomic instability through APC/C misregulation, and thus potentially contributes to tumorigenesis (Hsu et al., 2002). Upregulation of Emil mRNA has been found in a variety of malignant tumors compared to matched normal and benign tumor tissue. Notably, Emil protein is highly expressed in renal cell carcinomas, cervical adenocarcinomas, hepatocellular carcinomas, oligodendrogliomas, lung adenocarcinomas, endometrial cancers, of melanomas, many lymphomas and ovarian clear cell carcinoma (Lehman et al., 2006; Gütgemann et al., 2008). Emil expression is also related to the $\mathrm{pRB} / \mathrm{E} 2 \mathrm{~F}$ pathway since Emil is a target of the E2F transcription factor. At the G1-S transition Emil is transcriptionally induced by E2F, thus accelerating S phase entry (Hsu et al., 2002). The importance of this regulation is underscored by the finding that lack of $\mathrm{pRb}$ repression of E2F-mediated transcription causes misregulation of Emil and APC/C substrates in malignant tumors (Lehman et al., 2006).

\section{Sirt2}

Recently, the histone deacetylase (HDAC) SIRT2 has been shown to positively regulate APC/C activity (Kim et al., 2011). Histone acetyltransferases (HATs) and HDACs are enzymes controlling protein acetylation. Both target histones, whereas HATs catalyze the acetylation of histones and relax chromatin to increase accessibility of transcription factors to promoters of target genes, HDACs remove acetyl groups from histones and repress transcription (Strahl and Allis, 2000). Most of them have been found in transcription factor complexes and, therefore, have been considered to regulate transcription by modulating acetylation levels of chromatin (Kuo and Allis, 1998; Kouzarides, 1999). HDACs are important for cell cycle progression and their inhibition promote cell arrest in G1 and G2 (Marks et al., 2001; Johnstone and Licht, 2003; Noh and Lee, 2003). HDACs also have an important role in heterochromatin formation and maintenance (Olsson et al., 1999; Taddei et al., 2001) and are implicated in chromosome segregation (Nakayama et al., 2003; Silverstein et al., 2003; Kimata et al., 2008).

Several HDACs have a role in tumorigenesis, acting as a suppressors or promoters (Lagger et al., 2002; Glaser et al., 2003; Saunders and Verdin, 2007; Wang et al., 2008a,b; Deng, 2009; Bell et al., 2011; Kim et al., 2011) and HDAC inhibitors are a promising class of anti-cancer agents (Johnstone and Licht, 2003; Yoshida et al., 2003; Bolden et al., 2006). SIRT2 is predominantly localized in the cytoplasm where it deacetylates microtubules (North et al., 2003). During mitosis, SIRT2 is localized to chromosomes regulating chromosomal condensation (Vaquero et al., 2006; Inoue et al., 2007), and is also associated with mitotic structures, including the centrosome, mitotic spindle, and midbody, presumably to ensure normal cell division (North and Verdin, 2007). Kim et al. (2011) demonstrated that SIRT2 regulates APC/C activity through deacetylation of its coactivators Cdh1 and Cdc20. Deacetylation of Cdh1 and Cdc20 by SIRT2 enhances the interaction of these coactivators with $\mathrm{Cdc} 27$, leading to activation of APC/C. In Sirt2 mutant mice, reduced APC/C activity results in tumor formation by producing genomic instability associated with centrosome amplification, aneuploidy mitotic cell death, and spontaneous tumor formation. These deficiencies seem to be caused by a combined effect of altered expression of mitotic regulators that are controlled by APC/C (Figure 2). Accordingly, SIRT2 expression is reduced in several human malignancies including breast, liver, brain, kidney, and prostate cancers (Kim et al., 2011).

\section{PSMA AND MAK}

Mitotic defects associated with chromosomal aberrations are often observed in prostate cancer cells and tissue, suggesting possible misregulation by APC/C (Tribukait, 1991; Beheshti et al., 2001; Pihan et al., 2001). Two regulators of the APC/C have been found to be clearly involved in prostate cancer, prostate specific membrane antigen (PMSA) and male germ cell-associated kinase (MAK). PSMA is a type II transmembrane protein that exhibits both $N$-acetylated alpha-linked acidic peptidase (NAALADase) and folate hydrolase activities (Ghosh and Heston, 2004; Rajasekaran et al., 2005). PSMA is localized to secretory cells within the prostatic epithelium although its physiological and pathological functions remain unclear. PSMA is upregulated in advanced prostate carcinoma and metastatic disease (Rajasekaran et al., 2005), and is a feature of practically every prostatic tissue examined (Rajasekaran et al., 2005, 2008). PSMA is absent or moderately expressed in hyperplastic and benign tissues, while malignant tissues have high levels, demonstrating that PSMA expression increases proportionally to tumor aggressiveness (Troyer et al., 1995; Kawakami and Nakayama, 1997; Liu et al., 1997; Silver et al., 1997; Sweat et al., 1998; Chang et al., 1999, 2001; Burger et al., 2002; Ross et al., 2003). PSMA is localized to a membrane compartment in the vicinity of centrosomes at the spindle poles and associates with the APC/C subunit Cdc27 leading to 
premature activation of $\mathrm{APC} / \mathrm{C}$, and induction of aneuploidy (Rajasekaran et al., 2008). Increased APC/C activity observed in PSMA expressing cells is sufficient to impair the mitotic spindle checkpoint, which agrees with the finding that PSMA expressing cells exit mitosis prematurely (Figure 2). Therefore, PSMA may have a causal role in the progression of prostate cancer.

Male germ cell-associated kinase belongs to a protein kinase family characterized by a catalytic domain resembling a hybrid of the TXY motif found in mitogen-activated protein kinases (MAPK) and the TY motif in CDKs (Payne et al., 1991; Brown et al., 1999; Xia et al., 2002; Fu et al., 2005). MAK expression is elevated in castration-resistant prostate cancer cell lines and is generally overexpressed in prostate tumors, thus possibly contributing to malignancy via aberrant regulation of mitosis (Wang and Kung, 2011). MAK protein has a dynamic subcellular localization during the cell cycle: it is localized to the mitotic spindle and centrosomes during metaphase and anaphase, and to the mitotic midbody from anaphase to telophase. MAK negatively regulates $\mathrm{APC} / \mathrm{C}^{\mathrm{Cdh} 1}$ through interaction and phosphorylation of Cdh1 in CDK phosphorylated sites, in a manner reminiscent of CDK-dependent inactivation of Cdh1 (Wang and Kung, 2011; Figure 2). The phosphorylation of MAK increases between $\mathrm{S}$ and G2, peaks at early mitosis, and drastically decreases at the end of mitosis. This promotes the dissociation of Cdh1 and $\mathrm{APC} / \mathrm{C}$ thus decreasing $\mathrm{APC} / \mathrm{C}^{\mathrm{Cdh}} 1$ activity and promoting the stabilization of the substrates Aurora kinase A and Plk1. As overexpression of Aurora-A is known to induce centrosome amplification (Zhou et al., 1998), the extra-centrosomes observed in MAK overexpressed cells is likely due to cellular accumulation of Aurora-A.

\section{APC/C SUBSTRATES IN CANCER}

Many APC/C substrates have been implicated in a variety of human cancers (Table 2). For those substrates that are overexpressed in cancer it is important to note that overexpression of an APC/C substrate influences degradation of other APC/C substrates (Rape and Kirschner, 2004), suggesting that global estimates of APC/C substrate levels are required in normal and disease states. Further, while there are arguably many APC/C substrates that may be important for cancer progression, classifying their relative importance and druggability is essential.

\section{NIMA-RELATED KINASE 2}

The proteolysis of APC/C substrates starts as cells make the transition from G2 to M phase. One of the earliest targets is the NIMArelated kinase 2 (Nek2) family of serine/threonine protein kinases. They are implicated in the regulation of centrosome separation and spindle formation. Nek2A, along with cyclin $\mathrm{A}$ are unique $\mathrm{APC} / \mathrm{C}^{\mathrm{Cdc} 20}$ substrates that get degraded during prometaphase even when the SAC is active. A C-terminal dipeptide methioninearginine (MR) tail enables Nek2A to directly bind the APC/C independently of Cdc20 (Hayes et al., 2006). Nek2 levels are upregulated in human breast cancer, pediatric osteosarcoma, and B-cell lymphomas (Wai et al., 2002; de Vos et al., 2003; Hayward et al., 2004).

\section{CELL DIVISION CYCLE PROTEIN 20}

Cell division cycle protein 20 is an essential coactivator of the APC/C during mitosis. Multiple studies have indicated that maintaining appropriate Cdc20 levels is important for cellular homeostasis. When this is disturbed and Cdc20 is overexpressed, tumorigenesis can occur. For instance, oral squamous cell carcinomas (OSCC) and breast cancer cells overexpress Cdc20 causing premature anaphase and aneuploidy linked to tumor formation (Yuan et al., 2006; Mondal et al., 2007). Importantly, even a twofold overexpression of Cdc20 leads to spindle checkpoint defects and early Pds1 (securin) destruction producing aneuploidy (Pan and Chen, 2004).

One of the major ways Cdc20 protein levels are controlled is via the SAC. When the SAC is active during metaphase, the checkpoint proteins Mad2, BubR1, and Bub3 bind to Cdc20 and convert it into a substrate of $\mathrm{APC} / \mathrm{C}^{\mathrm{Cdc} 20}$. This allows for the ubiquitination and degradation of Cdc20 by APC/C ${ }^{\mathrm{Cdc} 20}$ (Nilsson et al., 2008; Ge et al., 2009). Thus, SAC activation inhibits Cdc20 and arrests cells in metaphase. Inactivation of SAC at the end of metaphase relieves this inhibition and Cdc20 promotes mitotic exit by degrading key substrates such as the mitotic cyclins. The importance of SAC dependent control of Cdc20 levels is underscored by the finding that anti-mitotic cancer drugs that activate the SAC cause cell cycle arrest. These drugs cause a prolonged metaphase arrest that may eventually lead to cell death. However, during this prolonged metaphase arrest, some Cdc20 escapes inhibition by the SAC and as a result, cyclin B1 levels start to fall and cells exit mitosis, thereby initiating mitotic slippage (Nilsson, 2011). This may be especially true in some cancer subtypes since the frequency of mitotic slippage is hastened in tumor cells lacking p53 and pRb (Depamphilis, 2011). Further, mitotic slippage reduces the sensitivity of tumor cells to chemotherapeutics. Thus, alternative means of inhibiting Cdc20 are needed.

Recent evidence suggests that targeting Cdc20 directly could be a better alternative than targeting the SAC in cancer therapy (Huang et al., 2009; Manchado et al., 2010). Knockdown of Cdc20 by siRNA induces mitotic arrest and apoptosis in various cancer cell lines that are otherwise resistant to apoptosis and prone to mitotic slippage (Huang et al., 2009). Further, genetic ablation of the $C d c 20$ gene in murine skin tumor and aggressive fibrosarcoma models results in complete tumor regression (Manchado et al., 2010). Cdc20 deletion induces metaphase arrest and apoptosis in tumor cells both in vitro and in vivo. Importantly, the activities of Cdk1 and Mast1 kinases are required for this arrest. When Cdk1 and Mast 1 kinases are inhibited, $C d c 20$ null cells exit mitosis via the activities of the phosphatases PP2A/B55 $\alpha$ and PP2A/B55 $\delta$ (Manchado et al., 2010). Thus, small molecules attenuating Cdc20 coupled with those inhibiting these phosphatases may be effective therapeutically.

\section{GEMININ}

Another APC/C substrate degraded at the metaphase-anaphase transition is geminin. It is a small $25 \mathrm{kDa}$ protein that inhibits DNA re-replication during $S$ phase. Geminin levels accumulate during $S, G 2$, and early mitosis. It suppresses the DNA replication factor CDT1 that is required for the formation of preRCs. Depletion of geminin by siRNA in tumor cells leads to DNA re-replication, cell 
cycle arrest, and apoptosis. However, regulation of CDT1 by geminin is found to be rate limiting for initiation of DNA replication only in cancer cells and not in normal or immortalized cells. Normal cells show the same effect only when cyclin A is co-depleted with geminin (Zhu and Depamphilis, 2009). Thus it has been proposed that inhibition of geminin activity can be used to selectively kill cancer cells (Zhu and Depamphilis, 2009).

\section{POLO-LIKE KINASE 1}

Toward the end of anaphase, the pro-mitotic regulatory kinase $\mathrm{Plk} 1$, is degraded by $\mathrm{APC} / \mathrm{C}^{\mathrm{Cdh} 1}$ in a D-box dependent manner (Lindon and Pines, 2004). Plk1 is a major kinase in eukaryotic cells involved in a variety of processes such as activation of the maturation promoting factor (MPF) by phosphorylation of Cdc25C and cyclin B1, bipolar spindle formation, and maturation of the centrosome (Ohkura et al., 1995; Lane and Nigg, 1996; Abrieu et al., 1998; Qian et al., 1998; Eckerdt et al., 2005). Elevated Plk1 levels are present in a broad spectrum of cancers including breast cancer, colorectal cancer, ovarian cancer, melanomas, pancreatic cancer, prostate cancer, lung cancer, and squamous cell carcinomas of the head and neck (Wolf et al., 1997, 2000; Knecht et al., 1999; Strebhardt et al., 2000; Macmillan et al., 2001; Gray et al., 2004; Weichert et al., 2004). This broad range of expression makes Plk1 a prime target in cancer (Strebhardt and Ullrich, 2006).

\section{AURORA-A}

Another APC/C $\mathrm{C}^{\mathrm{Cdh} 1}$ substrate during late mitosis is Aurora-A (STK15/BTAK), a serine/threonine kinase localized to the centrosome controlling mitotic spindle assembly and centrosome maturation. It is involved in a variety of human cancers (Bischoff et al., 1998; Zhou et al., 1998; Sen et al., 2002; Mondal et al., 2007). Ectopic expression of Aurora-A leads to chromosome instability and centrosome amplification (Miyoshi et al., 2001). One way it achieves this is by phosphorylating and regulating Centrin, the calcium-binding phosphoprotein located in the centrosome. Phosphorylated Centrin is more stable against $\mathrm{APC} / \mathrm{C}^{\mathrm{Cdh} 1}$ mediated destruction and an excess of it is thought to promote centrosome amplification in cancer (Lukasiewicz et al., 2011). Aurora-A itself becomes resistant to $\mathrm{APC} / \mathrm{C}^{\mathrm{Cdh} 1}$ mediated degradation when it is constitutively phosphorylated on Ser 51, and consequently gets overexpressed in head and neck cancers (Kitajima et al., 2007).

\section{HIGH EXPRESSION IN CANCER 1}

High expression in cancer 1 (HEC1), a recently identified APC/C ${ }^{\text {Cdh1 }}$ substrate, is part of the NDC80 complex controlling kinetochore microtubule dynamics. HEC1 levels peak during early mitosis and fall by telophase (Lipkowitz and Weissman, 2011). The mitotic regulatory kinase Nek2 phosphorylates HEC1 on Ser 165 thus activating it during G2/M. Inactivation of HEC1 results in severe chromosome segregation defects (Chen et al., 1997, 2002; Zheng et al., 1999). HEC1 is considered as a candidate marker for breast lesions likely to undergo malignant transformation because it is significantly overexpressed in benign breast tumors (Bieche et al., 2011). A small molecule called INH1, which binds to HEC1 and specifically disrupts the HEC1-Nek2 interaction, is found to suppress human breast cancer cell proliferation in culture as well as tumor growth in nude mice bearing xenografts (Wu et al., 2008).

\section{c-Jun NH2-TERMINAL KINASE}

c-Jun $\mathrm{NH}_{2}$-terminal kinase (JNKs), a class of MAPK, lead the cell's response to stress stimuli such as heat shock, radiation, and cytotoxic and genotoxic stress. Recently, nuclear JNK was found to be a substrate of $\mathrm{APC} / \mathrm{C}^{\mathrm{Cdh} 1}$ during late mitosis and $\mathrm{G} 1$ (Gutierrez et al., 2010a). JNK, in turn, controls APC/C Cdh1 by phosphorylating Cdh1 at three residues (Yu et al., 1998; Summers et al., 2008) to prevent premature Cdh1 association with the APC/C during G2. JNK-induced phosphorylation of key regulators not only controls cell survival and differentiation, but also cell cycle progression. JNK phosphorylates Cdc25C at Ser 168 in G2, downregulating its phosphatase activity required for CDK1 activation (Gutierrez et al., 2010b). This is required for the correct timing of mitotic entry and the proper establishment of G2/M checkpoint upon UV irradiation. However, constitutively active JNK causes defects in cell cycle progression. Indeed, many human tumors have been reported to require JNK activity for their growth and survival (Potapova et al., 2000; Antonyak et al., 2002; Tsuiki et al., 2003; Yang et al., 2003; Lopez-Bergami et al., 2007; Alexaki et al., 2008). In gastrointestinal cancers, a small molecule inhibitor of JNK shows promise as a therapeutic agent, because it induces cell cycle arrest and apoptosis (Xia et al., 2006).

\section{Ect2}

The oncogenic protein Ect 2 is ubiquitinated by APC/ $\mathrm{C}^{\mathrm{Cdh} 1}$ shortly after completion of mitosis (Liot et al., 2011). Ect2 is a positive regulator of the Rho GTPase pathway that controls cell cycle progression and cytokinesis (Bustelo et al., 2007). Many human tumors overexpress Ect2 (Sano et al., 2006; Salhia et al., 2008; Justilien and Fields, 2009; Justilien et al., 2011). Until now, this overexpression was believed to be a result of gene amplification and transcriptional upregulation (Seguin et al., 2009; Liot et al., 2011). But the newly discovered APC/ $\mathrm{C}^{\mathrm{Cdh} 1}$ dependent proteolysis of Ect2 shows that impaired destruction can also be a reason for increased Ect2 levels in tumor cells, which possibly asserts the role of Cdh1 as a tumor suppressor protein.

\section{Skp2}

Skp2 is one of the most important substrates targeted by APC/C $\mathrm{C}^{\mathrm{Cdh} 1}$ during mitotic exit. An SCF containing Skp2 targets the essential cell cycle substrates $\mathrm{p} 27^{\mathrm{Kip} 1}, \mathrm{p} 21^{\mathrm{Cip} 1}$, and FOXO1 for degradation (Yu et al., 1998; Tsvetkov et al., 1999; Huang et al., 2005). Destruction of the CDK inhibitor $\mathrm{p} 27^{\mathrm{Kip} 1}$ is a prerequisite for entry into mitosis. Once cells exit mitosis, APC/C $\mathrm{C}^{\mathrm{Cdh} 1}$ targets Skp2 for proteolysis in G1 (Bashir et al., 2004; Wei et al., 2004). Skp2 functions as an oncogene because most of its ubiquitination targets are tumor suppressor proteins. Thus overexpression of Skp2 is common in many cancers including breast cancer, prostate cancer, pancreatic cancer, hepatocellular carcinomas, melanomas, and malignant lymphomas (Lim et al., 2002; Yang et al., 2002; Radke et al., 2005; Lu et al., 2009; Rose et al., 2011; Schuler et al., 2011). Importantly, the Akt1 serine/threonine kinase phosphorylates Skp2 at Ser 72 promoting its cytoplasmic translocation and impairing degradation by APC/C ${ }^{C d h 1}$ (Gao et al., 2009b,c; Lin et al., 2009). Since the Aktl pathway is also found to be hyperactive in cancer cells, it may contribute significantly to overexpression of Skp2 protein found in some cancers (Gao et al., 
2009b,c). Opposing the Akt1 pathway is PTEN, which is frequently misregulated in human brain, breast, prostate cancers, and leukemias (Li et al., 1997; Dahia et al., 1999). Thus, PTEN misregulation may contribute to Akt1 hyperactivation and increased levels of Skp2 in tumors.

\section{Ube2C (UbcH10)}

Ube2C is an E2 enzyme that works exclusively with the APC/C throughout the cell cycle. However, Ube2C levels peak during mitosis and fall as cells enter G1, finally becoming a substrate for $\mathrm{APC} / \mathrm{C}^{\mathrm{Cdh} 1}$ at the end of G1 (Rape and Kirschner, 2004; Summers et al., 2008). When Ube2C is overexpressed in mouse embryonic fibroblasts (MEFs), precocious cyclin B1 degradation, mitotic slippage, and chromosome abnormalities have been observed (van
Ree et al., 2010). Importantly, elevated Ube2C levels is a common feature in a wide variety of human cancers including lung, prostate, breast, bladder, ovarian, uterine, thyroid, esophageal, and gastric carcinomas (Okamoto et al., 2003; Pallante et al., 2005; Berlingieri et al., 2007; Jiang et al., 2008; van Ree et al., 2010). Further, induced expression of high levels of Ube2C hastens tumor formation in transgenic mice (van Ree et al., 2010).

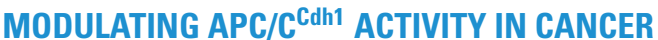 TARGETING APC/C Cdh1 $^{\text {SUBSTRATES }}$}

Several APC/C substrates are overexpressed in various cancers, making them prime targets for small molecule inhibition (Table 2). One potential APC/C substrate that could be targeted

Table 2 | Substrates of APC/C overexpressed in cancer.

\begin{tabular}{|c|c|c|c|c|}
\hline APC/C substrate & Major cell cycle function(s) & Role in tumorigenesis & Relevant cancers & Relevant reference \\
\hline Nek2 & $\begin{array}{l}\text { Regulation of centrosome } \\
\text { separation and spindle } \\
\text { formation }\end{array}$ & $\begin{array}{l}\text { Formation of multinucleated } \\
\text { cells with supernumerary } \\
\text { centrosomes }\end{array}$ & $\begin{array}{l}\text { Cervical cancer, B-cell } \\
\text { lymphoma, pediatric } \\
\text { osteosarcoma, breast cancer, } \\
\text { leukemia, ovarian cancer }\end{array}$ & $\begin{array}{l}\text { Wai et al. (2002), de Vos et al. } \\
\text { (2003), Hayward et al. (2004) }\end{array}$ \\
\hline Cdc20 & $\begin{array}{l}\text { Essential APC/C coactivator in } \\
\text { early mitosis }\end{array}$ & $\begin{array}{l}\text { Spindle checkpoint defects } \\
\text { and premature Securin } \\
\text { destruction leading to mitotic } \\
\text { slippage }\end{array}$ & $\begin{array}{l}\text { Oral squamous cell } \\
\text { carcinomas, breast cancer }\end{array}$ & $\begin{array}{l}\text { Yuan et al. (2006), Mondal et al. } \\
\text { (2007) }\end{array}$ \\
\hline Plk1 & $\begin{array}{l}\text { Activation of MPF by } \\
\text { phosphorylation of Cdc } 25 \mathrm{C} \\
\text { and Cyclin B Assembling the } \\
\text { mitotic spindle }\end{array}$ & $\begin{array}{l}\text { Overexpression in cancer } \\
\text { drives cells into mitosis }\end{array}$ & $\begin{array}{l}\text { Lung, ovarian, breast, colon, } \\
\text { prostate and pancreatic } \\
\text { cancers, head/neck squamous } \\
\text { cell carcinomas, melanomas }\end{array}$ & $\begin{array}{l}\text { Wolf et al. (1997), Knecht et al. } \\
\text { (1999), Strebhardt et al. (2000), } \\
\text { Wolf et al. (2000), Macmillan } \\
\text { et al. (2001), Gray et al. (2004), } \\
\text { Weichert et al. (2004) }\end{array}$ \\
\hline Aurora-A & $\begin{array}{l}\text { Controls centrosome } \\
\text { maturation and mitotic } \\
\text { spindle formation }\end{array}$ & $\begin{array}{l}\text { Induces centrosome } \\
\text { amplification and aneuploidy } \\
\text { by hindering APC/C }{ }^{\text {Cdh1 }} \\
\text { mediated destruction of } \\
\text { Centrin }\end{array}$ & $\begin{array}{l}\text { Bladder, lung, and colon } \\
\text { cancers }\end{array}$ & $\begin{array}{l}\text { Bischoff et al. (1998), Zhou et al. } \\
\text { (1998), Sen et al. (2002), Gu et al. } \\
\text { (2007) }\end{array}$ \\
\hline HEC1 & $\begin{array}{l}\text { Controls kinetochore } \\
\text { microtubule dynamics as part } \\
\text { of the NDC } 80 \text { complex }\end{array}$ & $\begin{array}{l}\text { Chromosome } \\
\text { mis-segregation }\end{array}$ & Breast cancer & Bieche et al. (2011) \\
\hline JNK & $\begin{array}{l}\text { Central role in stress } \\
\text { response pathways Ensures } \\
\text { correct timing of mitotic entry } \\
\text { by phosphorylating Cdc } 25 \mathrm{C}\end{array}$ & $\begin{array}{l}\text { Supports survival of tumor } \\
\text { cells by controlling cell cycle } \\
\text { arrest and apoptosis }\end{array}$ & $\begin{array}{l}\text { Brain tumors such as } \\
\text { glioblastoma, prostate cancer, } \\
\text { gastrointestinal cancers, } \\
\text { melanomas }\end{array}$ & $\begin{array}{l}\text { Potapova et al. (2000), Antonyak } \\
\text { et al. (2002), Tsuiki et al. (2003), } \\
\text { Yang et al. (2003), Xia et al. (2006), } \\
\text { Lopez-Bergami et al. (2007), Alex- } \\
\text { aki et al. (2008) }\end{array}$ \\
\hline Ect2 & $\begin{array}{l}\text { Positive regulator of the Rho } \\
\text { GTPase pathway that controls } \\
\text { actin cytoskeleton functions } \\
\text { like cytokinesis }\end{array}$ & $\begin{array}{l}\text { Ensures proper cytokinesis in } \\
\text { tumor cells }\end{array}$ & $\begin{array}{l}\text { Glioblastoma, non-small cell } \\
\text { lung cancer }\end{array}$ & $\begin{array}{l}\text { Salhia et al. (2008), Justilien et al. } \\
\text { (2011) }\end{array}$ \\
\hline Skp2 & $\begin{array}{l}\text { F-box protein that functions as } \\
\text { part of SCFSkp2 to degrade } \\
\text { Cdk inhibitors p2 } 7^{\text {Kip1 }} \text { and } \\
\text { p21 Cip1 }\end{array}$ & $\begin{array}{l}\text { Acts as an oncogene that } \\
\text { destroys tumor suppressor } \\
\text { proteins }\end{array}$ & $\begin{array}{l}\text { Breast, prostate, liver and } \\
\text { pancreatic cancers, } \\
\text { melanomas, lymphomas }\end{array}$ & $\begin{array}{l}\text { Lim et al. (2002), Radke et al. } \\
\text { (2005), Lu etal. (2009), Rose et al. } \\
\text { (2011), Schuler et al. (2011) }\end{array}$ \\
\hline Ube2C (UbcH10) & $\begin{array}{l}\text { Principal E2 enzyme the } \\
\text { APC/C collaborates with }\end{array}$ & $\begin{array}{l}\text { Chromosome abnormalities } \\
\text { and mitotic slippage }\end{array}$ & $\begin{array}{l}\text { Gastric carcinomas, cancers } \\
\text { of the lung, prostate, breast, } \\
\text { ovary, bladder, thyroid, uterus, } \\
\text { and esophagus }\end{array}$ & $\begin{array}{l}\text { Okamoto et al. (2003), Pallante } \\
\text { et al. (2005), Berlingieri et al. } \\
\text { (2007), Jiang et al. (2008), van } \\
\text { Ree et al. (2010) }\end{array}$ \\
\hline
\end{tabular}


via such a strategy is the proto-oncogene Skp2 (Fujita et al., 2008, 2009). Downregulation of Skp2 by antisense RNA treatment induces apoptosis in lung cancer cells (Yokoi et al., 2003). Therefore, one possibility is utilizing compounds affecting Skp2 expression. For instance, treatment with EB1089 (vitamin D ana$\log$ ) reduces Skp2 expression in treated cancer cells, thus promoting increased stability of $\mathrm{p} 27^{\mathrm{Kip} 1}$ protein and subsequent growth arrest (Lin et al., 2003; Figure 3). Skp2 expression is also affected by treatment with retinoic acid, thus altering the ability of $\mathrm{p} 27^{\mathrm{Kip} 1}$ to be ubiquitinated (Nakamura et al., 2003). Furthermore, the PPARg agonist Troglitazone reduces $S k p 2$ mRNA levels, leading to p27 ${ }^{\text {Kip1 }}$ accumulation (Koga et al., 2003).

Since the APC/C mediates Skp2 ubiquitination, enhancing APC/C dependent degradation of Skp2 in cancer would also be therapeutically attractive. One possible means of achieving this is to inhibit casein kinase 1 (CK1), which controls APC/C dependent degradation of Skp2 (Gao et al., 2009b,c). CK1 inhibition induces Skp2 degradation since CK1 dependent phosphorylation normally inhibits Skp2 nuclear translocation and interaction with APC/C ${ }^{C d h 1}$ (Gao et al., 2009b,c). An alternative strategy, however, could be increasing the affinity of Skp2 or other oncogenic substrates for APC/C, thus reducing their protein levels after ubiquitination and degradation. The advent of high-throughput screens to study APC/C-dependent degradation and protein-protein interactions will facilitate identification of small molecule agonists of the APC/C-Skp2 interaction (Madoux et al., 2010; Zeng et al., 2010).

Another potential APC/C cancer target is the substrate Aurora$\mathrm{A}$, since its overexpression is known to induce centrosome amplification and is overexpressed in human cancer cells (Zhou et al., 1998). Recently, several compounds have been found to target Aurora-A (Figure 3). Curcumin, an active compound in turmeric and curry that has been proven to induce tumor apoptosis and inhibit tumor proliferation, invasion, angiogenesis, and metastasis, has been shown to reduce Aurora- $A$ mRNA expression in human bladder cancer cells (Liu et al., 2011a). These curcumininduced phenomena were similar to those using Aurora-A small interfering RNA and were attenuated by ectopic expression of
Aurora-A. Also, several cyclic peptide ligands inhibiting Aurora-A kinase activity have been developed (Shomin et al., 2011), although future studies regarding proliferation of cancer cells still have to be performed.

In addition to Aurora-A inhibition, there is pharmaceutical interest in targeting Plk1 as Plk1 depletion in cancer cells dramatically inhibits cell proliferation and decreases viability (Liu and Erikson, 2003; Xu et al., 2011; Yoon et al., 2011). Depletion of Plk1 perturbs spindle assembly, which leads to activation of the mitotic checkpoint, prolonged mitotic arrest, and eventually apoptosis (Liu and Erikson, 2003). Thus, given the known functions and effects of Plk1 inhibition, coupled with its wide overexpression pattern in cancer, a naturally occurring Plk1 inhibitor with low or no toxicity will be immensely useful in prevention as well as treatment of cancer. Numerous Plk1 inhibitors are in development to evaluate their potential as treatments in oncology, some of them in preclinical and clinical phase I/II development (Schöffski, 2009; Figure 3). It will be interesting to determine whether enhancing APC/C mediated degradation of Plk1 yield similar therapeutic benefits as Plk1 inhibitors currently in clinical trials.

\section{TARGETING APC/C ${ }^{\text {Cdh1 }}$ ACTIVITY}

Several lines of evidence suggest that modulation of the APC/C complex is a good anti-cancer therapeutic strategy. Downregulation of the catalytic subunits Apc 2 and Apc1 1 leads to growth arrest and cell death in HeLa cells (Pray et al., 2002). Also, a small molecule, tosyl-L-arginine methyl ester (TAME), which binds to APC/C and prevents its activation by $\mathrm{Cdc} 20$ and $\mathrm{Cdh} 1$, produces mitotic arrest (Zeng et al., 2010; Figure 3). Furthermore, expression of several APC/C subunits is higher in tumor relative to normal tissue (Wang et al., 2003). Collectively, these studies suggest that pharmacological interference with APC/C activity through disruption of protein-protein interaction is likely to have potent anti-tumor activity (Pray et al., 2002; Huang et al., 2009).

Targeting upstream regulators of the APC/C complex controlling mitosis is also a promising strategy. Overexpression of APC/C inhibitors such as Emil in mammalian cells impedes cell cycle progression and results in cell death (Reimann et al., 2001). HDACs

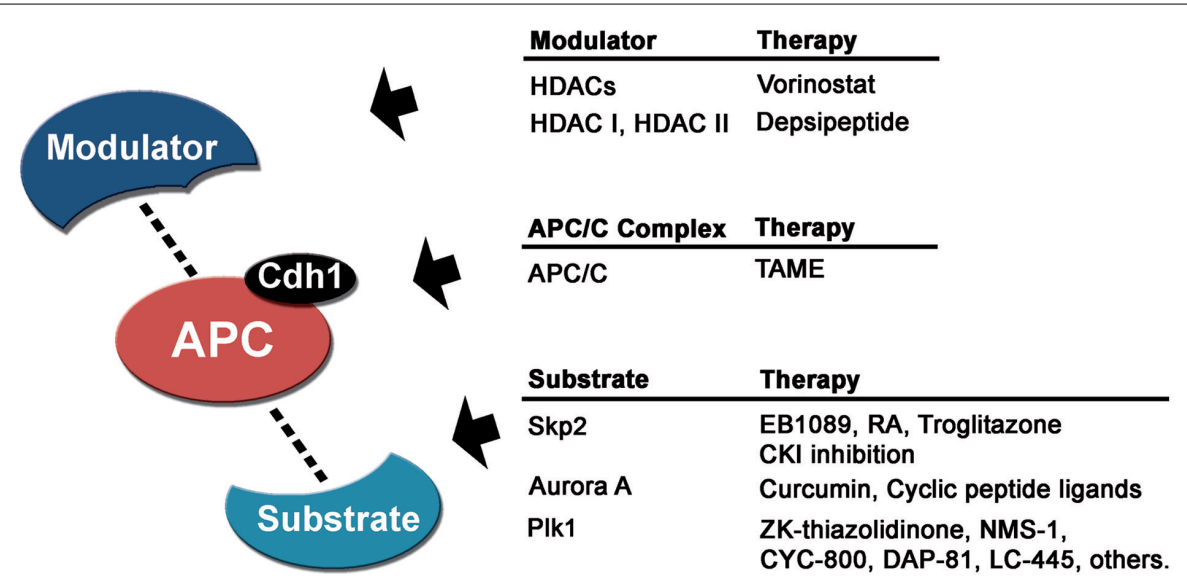

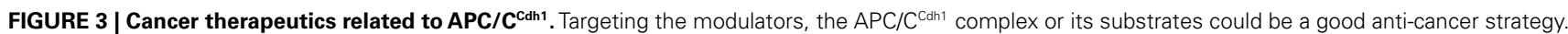
Some pharmacological treatments that regulate APC/C activity or substrate levels are currently in clinical trials or under development. 
might directly target APC/C to ensure proper chromosome segregation and anti-tumor effects of HDAC inhibitors could be attributed to this deregulation (Kimata et al., 2008). There are emerging HDAC inhibitors that have been clinically validated as therapeutic agents in cancer patients with hematologic malignancies. Two HDAC inhibitors, vorinostat (pan-HDAC inhibitor) and depsipeptide (HDAC 1 and II inhibitor) have been approved by the FDA and are under further clinical investigation (Figure 3). HDAC inhibitors are well tolerated and clinically effective against hematologic cancers (Duvic and Vu, 2007; Luu et al., 2008; Modesitt et al., 2008).

\section{CONCLUDING REMARKS}

The APC/C is a unique ubiquitin ligase since it possesses a distinct structure and interacts with specific E2 enzymes required for mediating substrate ubiquitination. Further, $\mathrm{APC} / \mathrm{C}^{\mathrm{Cdc} 20}$ activity is essential in vitro and in vivo, suggesting that no other ubiquitin ligase can substitute for APC/C's role during mitosis (Li et al., 2007; Manchado et al., 2010). Similarly, APC/C ${ }^{\text {Cdh1 }}$ activity is required

\section{REFERENCES}

Abrieu, A., Brassac, T., Galas, S., Fisher, D., Labbe, J. C., and Doree, M. (1998). The polo-like kinase Plx1 is a component of the MPF amplification loop at the G2/M-phase transition of the cell cycle in Xenopus eggs. J. Cell Sci. 111, 1751-1757.

Acquaviva, C., and Pines, J. (2006). The anaphase-promoting complex/cyclosome: APC/C. J. Cell Sci. 119, 2401-2404.

Albanese, C., Johnson, J., Watanabe, G., Eklund, N., Vu, D., Arnold, A., and Pestell, R. G. (1995). Transforming p21ras mutants and c-ets-2 activate the cyclin D1 promoter through distinguishable regions. J. Biol. Chem. 270, 23589-23597.

Alexaki, V. I., Javelaud, D., and Mauviel, A. (2008). JNK supports survival in melanoma cells by controlling cell cycle arrest and apoptosis. Pigment Cell Melanoma Res. 21, 429-438.

Almeida, A., Bolanos, J. P., and Moreno, S. (2005). Cdh1/Hct1-APC is essential for the survival of postmitotic neurons. J. Neurosci. 25, 8115-8121.

Antonyak, M. A., Kenyon, L. C., Godwin, A. K., James, D. C., Emlet, D. R., Okamoto, I., Tnani, M., HolgadoMadruga, M., Moscatello, D. K., and Wong, A. J. (2002). Elevated JNK activation contributes to the pathogenesis of human brain tumors. Oncogene 21, 5038-5046.

Araki, M., Wharton, R. P., Tang, Z., Yu, H., and Asano, M. (2003). Degradation of origin recognition complex large subunit by the anaphase-promoting complex in drosophila. EMBO J. 22, 6115-6126.
Baghdoyan, S., Lamartine, J., Castel, D., Pitaval, A., Roupioz, Y., Franco, N., Duarte, M., Martin, M. T., and Gidrol, X. (2005). Id2 reverses cell cycle arrest induced by \{gamma\}-irradiation in human HaCaT keratinocytes. J. Biol. Chem. 280, 15836-15841.

Barford, D. (2011). Structure, function and mechanism of the anaphase promoting complex (APC/C). Q. Rev. Biophys. 44, 153-190.

Bar-On, O., Shapira, M., Skorecki, K., Hershko, A., and Hershko, D. D. (2010). Regulation of APC/C (Cdh1) ubiquitin ligase in differentiation of human embryonic stem cells. Cell Cycle 9, 1986-1989.

Bashir, T., Dorrello, N. V., Amador, V., Guardavaccaro, D., and Pagano, M. (2004). Control of the SCF(Skp2Cks1) ubiquitin ligase by the $\mathrm{APC} / \mathrm{C}(\mathrm{Cdh} 1)$ ubiquitin ligase. Nature 428, 190-193.

Bassermann, F., Frescas, D., Guardavaccaro, D., Busino, L., Peschiaroli, A., and Pagano, M. (2008). The Cdc14B-Cdh1-Plk1 axis controls the G2 DNA-damage-response checkpoint. Cell 134, 256-267.

Beheshti, B., Park, P. C., Sweet, J. M., Trachtenberg, J., Jewett, M. A., and Squire, J. A. (2001). Evidence of chromosomal instability in prostate cancer determined by spectral karyotyping (SKY) and interphase fish analysis. Neoplasia 3, 62-69.

Bell, E. L., Emerling, B. M., Ricoult, S. J., and Guarente, L. (2011). SirT3 suppresses hypoxia inducible factor lalpha and tumor growth by inhibiting mitochondrial ROS production. Oncogene 30, 2986-2996.

for cell cycle traverse, differentiation, placental formation, and for inhibiting tumorigenesis (Garcia-Higuera et al., 2008; Li et al., 2008). These exciting studies suggest that APC/C plays a large role in normal cell proliferation, which may be misregulated during cancer. Consistent with this notion are new studies linking APC/C substrates and regulators to tumor formation. Thus, it may be attractive to modulate $\mathrm{APC} / \mathrm{C}$ substrate or regulator interaction pharmacologically to ablate tumor growth, which would have the advantage that specific interactions relevant to a cancer type can be uniquely targeted.

\section{ACKNOWLEDGMENTS}

We thank Ms. Satu Hyvarinen for helpful discussions and critical reading of the manuscript. We thank all members of the Wahlestedt laboratory and the Center for Therapeutic Innovation for helpful discussions. We apologize if we have omitted studies linking APC/C modulators and substrates to differentiation or tumorigenesis due to space constraints. This work was supported by R01NS067289-03.

Benmaamar, R., and Pagano, M. (2005). Involvement of the SCF complex in the control of Cdhl degradation in S-phase. Cell Cycle 4, 1230-1232.

Berlingieri, M. T., Pallante, P., Guida, M., Nappi, C., Masciullo, V., Scambia, G., Ferraro, A., Leone, V., Sboner, A. Barbareschi, M., Ferro, A., Troncone, G., and Fusco, A. (2007). UbcH10 expression may be a useful tool in the prognosis of ovarian carcinomas. Oncogene 26, 2136-2140.

Bieche, I., Vacher, S., Lallemand, F., Tozlu-Kara, S., Bennani, H. Beuzelin, M., Driouch, K., Rouleau, E., Lerebours, F., Ripoche, H., Cizeron-Clairac, G., Spyratos, F., and Lidereau, R. (2011). Expression analysis of mitotic spindle checkpoint genes in breast carcinoma: role of NDC80/HEC1 in early breast tumorigenicity, and a two-gene signature for aneuploidy. Mol. Cancer 10, 23.

Binné, U. K., Classon, M. K., Dick, F. A., Wei, W., Rape, M., Kaelin, W. G. Jr, Näär, A. M., and Dyson, N. J. (2007). Retinoblastoma protein and anaphase-promoting complex physically interact and functionally cooperate during cell-cycle exit. Nat. Cel Biol. 9, 225-232.

Bischoff, J. R., Anderson, L., Zhu, Y., Mossie, K., Ng, L., Souza, B. Schryver, B., Flanagan, P., Clairvoyant, F., Ginther, C., Chan, C. S. Novotny, M., Slamon, D. J., and Plowman, G. D. (1998). A homologue of Drosophila aurora kinase is oncogenic and amplified in human colorectal cancers. EMBO J. 17, 3052-3065.
Blanco-Aparicio, C., Renner, O., Leal, J. F., and Carnero, A. (2007). PTEN, more than the AKT pathway. Carcinogenesis 28, 1379-1386.

Bolden, J. E., Peart, M. J., and Johnstone, R. W. (2006). Anticancer activities of histone deacetylase inhibitors. Nat. Rev. Drug Discov. 5, 769-784.

Bornstein, G., Bloom, J., Sitry-Shevah, D., Nakayama, K., Pagano, M., and Hershko, A. (2003). Role of the SCFSkp2 ubiquitin ligase in the degradation of p21Cip1 in S phase. J. Biol. Chem. 278, 25752-25757.

Brandeis, M., and Hunt, T. (1996) The proteolysis of mitotic cyclins in mammalian cells persists from the end of mitosis until the onset of $\mathrm{S}$ phase. EMBO J. 15 , 5280-5289.

Brown, N. R., Noble, M. E., Lawrie, A. M., Morris, M. C., Tunnah, P., Divita, G., Johnson, L. N., and Endicott, J. A. (1999). Effects of phosphorylation of threonine 160 on cyclin-dependent kinase 2 structure and activity. J. Biol. Chem. 274 8746-8756.

Burger, M. J., Tebay, M. A., Keith, P. A., Samaratunga, H. M., Clements, J., Lavin, M. F., and Gardiner, R. A. (2002). Expression analysis of delta-catenin and prostatespecific membrane antigen: their potential as diagnostic markers for prostate cancer. Int. J. Cancer 100, 228-237.

Bustelo, X. R., Sauzeau, V., and Berenjeno, I. M. (2007). GTP-binding proteins of the Rho/Rac family: regulation, effectors and functions in vivo. Bioessays 29, 356-370. 
Cairns, P., Okami, K., Halachmi, S., Halachmi, N., Esteller, M., Herman, J. G., Jen, J., Isaacs, W. B., Bova, G. S., and Sidransky, D. (1997). Frequent inactivation of PTEN/MMAC1 in primary prostate cancer. Cancer Res. 57, 4997-5000.

Carrano, A. C., Eytan, E., Hershko, A., and Pagano, M. (1999). SKP2 is required for ubiquitin-mediated degradation of the CDK inhibitor p27. Nat. Cell Biol. 1, 193-199.

Carruthers, S., Mason, J., and Papalopulu, N. (2003). Depletion of the cell-cycle inhibitor p27(Xic1) impairs neuronal differentiation and increases the number of ElrC $(+)$ progenitor cells in Xenopus tropicalis. Mech. Dev. 120, 607-616.

Chabes, A. L., Pfleger, C. M., Kirschner, M. W., and Thelander, L. (2003). Mouse ribonucleotide reductase R2 protein: a new target for anaphase-promoting complexCdhl-mediated proteolysis. Proc. Natl. Acad. Sci. U.S.A. 100, 3925-3929.

Chalhoub, N., and Baker, S. J. (2009). PTEN and the PI3-kinase pathway in cancer. Annu. Rev. Pathol. 4, 127-150.

Chang, S. S., Reuter, V. E., Heston, W. D., Bander, N. H., Grauer, L. S., and Gaudin, P. B. (1999). Five different anti-prostate-specific membrane antigen (PSMA) antibodies confirm PSMA expression in tumorassociated neovasculature. Cancer Res. 59, 3192-3198.

Chang, S. S., Reuter, V. E., Heston, W. D., and Gaudin, P. B. (2001). Comparison of anti-prostate-specific membrane antigen antibodies and other immunomarkers in metastatic prostate carcinoma. Urology 57, 1179-1183.

Chaudhary, J., Sadler-Riggleman, I., Ague, J. M., and Skinner, M. K. (2005). The helix-loop-helix inhibitor of differentiation (ID) proteins induce post-mitotic terminally differentiated sertoli cells to re-enter the cell cycle and proliferate. Biol. Reprod. 72, 1205-1217.

Chen, H. Z., Tsai, S. Y., and Leone, G. (2009). Emerging roles of E2Fs in cancer: an exit from cell cycle control. Nat. Rev. Cancer 9, 785-797.

Chen, Y., Riley, D. J., Chen, P. L., and Lee, W. H. (1997). HEC, a novel nuclear protein rich in leucine heptad repeats specifically involved in mitosis. Mol. Cell. Biol. 17, 6049-6056.

Chen, Y., Riley, D. J., Zheng, L., Chen, P. L., and Lee, W. H. (2002). Phosphorylation of the mitotic regulator protein $\mathrm{Hecl}$ by $\mathrm{Nek} 2$ kinase is essential for faithful chromosome segregation. J. Biol. Chem. 277, 49408-49416.

Classon, M., and Harlow, E. (2002). The retinoblastoma tumour suppressor in development and cancer. Nat. Rev. Cancer 2, 910-917.

Cobrinik, D. (2005). Pocket proteins and cell cycle control. Oncogene 24, 2796-2809.

Cochrane, S. W., Zhao, Y., Welner, R. S., and Sun, X. H. (2009). Balance between id and E proteins regulates myeloid-versuslymphoid lineage decisions. Blood 113, 1016-1026.

Contestabile, A., Fila, T., Bartesaghi, R., and Ciani, E. (2009). Cell cycle elongation impairs proliferation of cerebellar granule cell precursors in the Ts65Dn mouse, an animal model for down syndrome. Brain Pathol. 19, 224-237.

Cotto-Rios, X. M., Jones, M. J., Busino, L., Pagano, M., and Huang, T. T. (2011). APC/CCdh1-dependent proteolysis of USP1 regulates the response to UV-mediated DNA damage. J. Cell Biol. 194, 177-186.

Cuende, J., Moreno, S., Bolanos, J. P. and Almeida, A. (2008). Retinoic acid downregulates Rael leading to APC(Cdh1) activation and neuroblastoma SH-SY5Y differentiation. Oncogene 27, 3339-3344.

Dahia, P. L., Aguiar, R. C., Alberta, J. Kum, J. B., Caron, S., Sill, H., Marsh, D. J., Ritz, J., Freedman, A., Stiles, C., and Eng, C. (1999). PTEN is inversely correlated with the cell survival factor $\mathrm{Akt} / \mathrm{PKB}$ and is inactivated via multiple mechanismsin haematological malignancies. Hum. Mol. Genet. 8, 185-193.

Daley, G. Q. (2008). Common themes of dedifferentiation in somatic cell reprogramming and cancer. Cold Spring Harb. Symp. Quant. Biol. 73, 171-174.

de Vos, S., Hofmann, W. K., Grogan, T. M., Krug, U., Schrage, M., Miller, T. P., Braun, J. G., Wachsman, W., Koeffler, H. P., and Said, J. W. (2003). Gene expression profile of serial samples of transformed B-cell lymphomas. Lab. Invest. 83, 271-285.

Deng, C. X. (2009). SIRT1, is it a tumor promoter or tumor suppressor? Int J. Biol. Sci. 5, 147-152.

Denning, G., Jean-Joseph, B., Prince, C., Durden, D. L., and Vogt, P. K. (2007). A short N-terminal sequence of PTEN controls cytoplasmic localization and is required for suppression of cell growth. Oncogene 26, 3930-3940.
Depamphilis, M. L. (2011). Spotlight on geminin. Breast Cancer Res. 13, 109.

Di Cristofano, A., Pesce, B., CordonCardo, C., and Pandolfi, P. P. (1998) Pten is essential for embryonic development and tumour suppression. Nat. Genet. 19, 348-355.

Diffley, J. F. (2004). Regulation of early events in chromosome replication. Curr. Biol. 14, R778-R786.

Dube, P., Herzog, F., Gieffers, C., Sander, B., Riedel, D., Muller, S. A., Engel, A., Peters, J. M., and Stark, H. (2005). Localization of the coactivator Cdh1 and the cullin subunit Apc2 in a cryo-electron microscopy model of vertebrate APC/C. Mol. Cell 20, 867-879.

Durand, B., Fero, M. L., Roberts, J. M., and Raff, M. C. (1998). p27Kipl alters the response of cells to mitogen and is part of a cell-intrinsic timer that arrests the cell cycle and initiates differentiation. Curr. Biol. 8 , 431-440.

Duvic, M., and Vu, J. (2007). Vorinostat: a new oral histone deacetylase inhibitor approved for cutaneous Tcell lymphoma. Expert Opin. Investig. Drugs 16, 1111-1120.

Eckerdt, F., Yuan, J., and Strebhardt, K. (2005). Polo-like kinases and oncogenesis. Oncogene 24, 267-276.

Eckerle, I., Muth, D., Batzler, J., Henrich, K. O., Lutz, W., Fischer, M., Witt, O., Schwab, M., and Westermann, F. (2009). Regulation of BIRC5 and its isoform BIRC5-2B in neuroblastoma. Cancer Lett. 285, 99-107.

Engelbert, D., Schnerch, D., Baumgarten, A., and Wasch, R. (2008) The ubiquitin ligase $\mathrm{APC}(\mathrm{Cdh} 1)$ is required to maintain genome integrity in primary human cells. Oncogene 27, 907-917.

Fang, G., Yu, H., and Kirschne, M. W. (1998). Direct binding of CDC20 protein family members activates the anaphase-promoting complex in mitosis and G1. Mol. Cell 2, 163-171.

Feilotter, H. E., Nagai, M. A., Boag, A. H. Eng, C., and Mulligan, L. M. (1998) Analysis of PTEN and the 10q23 region in primary prostate carcinomas. Oncogene 16, 1743-1748.

Fero, M. L., Rivkin, M., Tasch, M., Porter P., Carow, C. E., Firpo, E., Polyak K., Tsai, L. H., Broudy, V., Perlmutter, R. M., Kaushansky, K., and Roberts, J. M. (1996). A syndrome of multiorgan hyperplasia with features of gigantism, tumorigenesis, and female sterility in p27(Kip1)deficient mice. Cell 85, 733-744.

Fu, Z., Schroeder, M. J., Shabanowitz, J., Kaldis, P., Togawa, K., Rustgi, A. K., Hunt, D. F., and Sturgill, T. W. (2005). Activation of a nuclear Cdc2-related kinase within a mitogen-activated protein kinaselike TDY motif by autophosphorylation and cyclin-dependent protein kinase-activating kinase. Mol. Cell. Biol. 25, 6047-6064.

Fujita, T., Liu, W., Doihara, H., and Wan, Y. (2008). Regulation of Skp2p27 axis by the Cdhl/anaphasepromoting complex pathway in colorectal tumorigenesis. Am. J. Pathol. 173, 217-228.

Fujita, T., Liu, W., Doihara, H., and Wan, Y. (2009). An in vivo study of Cdh1/APC in breast cancer formation. Int. J. Cancer 125, 826-836.

Ganoth, D., Bornstein, G., Ko, T. K. Larsen, B., Tyers, M., Pagano, M., and Hershko, A. (2001). The cellcycle regulatory protein $\mathrm{Cksl}$ is required for $\mathrm{SCF}(\mathrm{Skp} 2)$-mediated ubiquitinylation of p27. Nat. Cell Biol. 3, 321-324.

Gao, D., Inuzuka, H., Korenjak, M., Tseng, A., Wu, T., Wan, L., and Kirschner M, Dyson N, Wei W. (2009a). Cdh1 regulates cell cycle through modulating the claspin/Chk1 and the Rb/E2F1 pathways. Mol. Biol. Cell 20, 3305-3316.

Gao, D., Inuzuka, H., Tseng, A., Chin, R. Y., Toker, A., and Wei, W. (2009b). Phosphorylation by Aktl promotes cytoplasmic localization of Skp2 and impairs APCCdh1mediated Skp2 destruction. Nat. Cell Biol. 11, 397-408.

Gao, D., Inuzuka, H., Tseng, A., and Wei, W. (2009c). Akt finds its new path to regulate cell cycle through modulating Skp2 activity and its destruction by APC/Cdh1. Cell Div. 4, 11 .

Garcia-Higuera, I., Manchado, E., Dubus, P., Canamero, M., Mendez, J., Moreno, S., and Malumbres, M. (2008). Genomic stability and tumour suppression by the APC/C cofactor Cdh1. Nat. Cell Biol. 10, 802-811.

Garnett, M. J., Mansfeld, J., Godwin, C., Matsusaka, T., Wu, J., Russell, P., Pines, J., and Venkitaraman, A. R. (2009). UBE2S elongates ubiquitin chains on APC/C substrates to promote mitotic exit. Nat. Cell Biol. 11, 1363-1369.

Gayraud-Morel, B., Chretien, F., Flamant, P., Gomes, D., Zammit, P. S., and Tajbakhsh, S. (2007). A role for the myogenic determination gene Myf5 in adult regenerative myogenesis. Dev. Biol. 312, 13-28.

Ge, S., Skaar, J. R., and Pagano, M. (2009). APC/C- and Mad2mediated degradation of Cdc20 during spindle checkpoint activation. Cell Cycle 8, 167-171. 
Georgescu, M. M., Kirsch, K. H., Kaloudis, P., Yang, H., Pavletich, N. P., and Hanafusa, H. (2000). Stabilization and productive positioning roles of the C2 domain of PTEN tumor suppressor. Cancer Res. 60, 7033-7038.

Ghosh, A., and Heston, W. D. (2004). Tumor target prostate specific membrane antigen (PSMA) and its regulation in prostate cancer. J. Cell. Biochem. 91, 528-539.

Gieffers, C., Dube, P., Harris, J. R., Stark, H., and Peters, J. M. (2001). Three-dimensional structure of the anaphase-promoting complex. Mol. Cell 7, 907-913.

Gieffers, C., Peters, B. H., Kramer, E. R., Dotti, C. G., and Peters, J. M. (1999). Expression of the CDH1associated form of the anaphasepromoting complex in postmitotic neurons. Proc. Natl. Acad. Sci. U.S.A. 96, 11317-11322.

Gildea, J. J., Herlevsen, M., Harding, M. A., Gulding, K. M., Moskaluk, C. A., Frierson, H. F., and Theodorescu, D. (2004). PTEN can inhibit in vitro organotypic and in vivo orthotopic invasion of human bladder cancer cells even in the absence of its lipid phosphatase activity. Oncogene 23, 6788-6797.

Glaser, K. B., Li, J., Staver, M. J., Wei, R. Q., Albert, D. H., and Davidsen, S. K. (2003). Role of class I and class II histone deacetylases in carcinoma cells using siRNA. Biochem. Biophys. Res. Commun. 310, 529-536.

Glotzer, M., Murray, A. W., and Kirschner, M. W. (1991). Cyclin is degraded by the ubiquitin pathway. Nature 349, 132-138.

Gmachl, M., Gieffers, C., Podtelejnikov, A. V., Mann, M., and Peters, J. M. (2000). The RING-H2 finger protein APC11 and the E2 enzyme UBC4 are sufficient to ubiquitinate substrates of the anaphase-promoting complex. Proc. Natl. Acad. Sci. U.S.A. 97, 8973-8978.

Gray, I. C., Stewart, L. M., Phillips, S. M., Hamilton, J. A., Gray, N. E., Watson, G. J., Spurr, N. K., and Snary, D. (1998). Mutation and expression analysis of the putative prostate tumour-suppressor gene PTEN. $\mathrm{Br}$. J. Cancer 78, 1296-1300.

Gray, P. J., Bearss, D. J., Han, H., Nagle, R., Tsao, M. S., Dean, N., and Von Hoff, D. D. (2004). Identification of human polo-like kinase 1 as a potential therapeutic target in pancreatic cancer. Mol. Cancer Ther. 3, 641-646.

Gu, J., Gong, Y., Huang, M., Lu, C., Spitz, M. R., and Wu, X. (2007). Polymorphisms of STK15 (aurora-A) gene and lung cancer risk in Caucasians. Carcinogenesis 28, 350-355.

Guardavaccaro, D., Kudo, Y., Boulaire, J., Barchi, M., Busino, L., Donzelli, M., Margottin-Goguet, F., Jackson, P. K., Yamasaki, L., and Pagano, M. (2003). Control of meiotic and mitotic progression by the $\mathrm{F}$ box protein betaTrcp1 in vivo. Dev. Cell 4, 799-812.

Gütgemann, I., Lehman, N. L., Jackson, P. K., and Longacre, T A. (2008). Emil protein accumulation implicates misregulation of the anaphase promoting complex/cyclosome pathway in ovarian clear cell carcinoma. Mod. Pathol.21, 445-454.

Gutierrez, G. J., Tsuji, T., Chen, M., Jiang, W., and Ronai, Z. A. (2010a). Interplay between Cdh1 and JNK activity during the cell cycle. Nat. Cell Biol. 12, 686-695.

Gutierrez, G. J., Tsuji, T., Cross, J. V., Davis, R. J., Templeton, D. J., Jiang, W., and Ronai, Z. A. (2010b). JNK-mediated phosphorylation of Cdc25C regulates cell cycle entry and G(2)/M DNA damage checkpoint. J. Biol. Chem. 285, 14217-14228.

Hansen, D. V., Loktev, A. V., Ban, K. H., and Jackson, P. K. (2004). Plk1 regulates activation of the anaphase promoting complex by phosphorylating and triggering SCFbetaTrCPdependent destruction of the APC inhibitor Emil. Mol. Biol. Cell 15, 5623-5634.

Harmey, D., Smith, A., Simanski, S., Moussa, C. Z., and Ayad, N. G. (2009). The anaphase promoting complex induces substrate degradation during neuronal differentiation. J. Biol. Chem. 284, 4317-4323.

Havrda, M. C., Harris, B. T., Mantani, A., Ward, N. M., Paolella, B. R., Cuzon, V. C., Yeh, H. H., and Israel, M. A. (2008). Id2 is required for specification of dopaminergic neurons during adult olfactory neurogenesis. $J$. Neurosci. 28, 14074-14086.

Hayes, M. J., Kimata, Y., Wattam, S. L., Lindon, C., Mao, G., Yamano, H., and Fry, A. M. (2006). Early mitotic degradation of Nek2A depends on Cdc20-independent interaction with the APC/C. Nat. Cell Biol. 8, 607-614.

Hayward, D. G., Clarke, R. B., Faragher, A. J., Pillai, M. R., Hagan, I. M., and Fry, A. M. (2004). The centrosomal kinase Nek2 displays elevated levels of protein expression in human breast cancer. Cancer Res. 64, 7370-7376.

Hollander, M. C., Blumenthal, G. M., and Dennis, P. A. (2011). PTEN loss in the continuum of common cancers, rare syndromes and mouse models. Nat. Rev. Cancer 11, 289 301.

Hsu, J. Y., Reimann, J. D., Sorensen, C. S., Lukas, J., and Jackson, P. K. (2002). E2F-dependent accumulation of hEmil regulates $S$ phase entry by inhibiting APC(Cdh1). Nat. Cell Biol. 4, 358-366.

Huang, H., Regan, K. M., Wang, F., Wang, D., Smith, D. I., van Deursen, J. M., and Tindall, D. J. (2005). Skp2 inhibits FOXO1 in tumor suppression through ubiquitin-mediated degradation. Proc. Natl. Acad. Sci. U.S.A. 102, 1649-1654.

Huang, H. C., Shi, J., Orth, J. D., and Mitchison, T. J. (2009). Evidence that mitotic exit is a better cancer therapeutic target than spindle assembly. Cancer Cell 16, 347-358.

Hutchins, J. R., Toyoda, Y., Hegemann, B., Poser, I., Heriche, J. K., Sykora M. M., Augsburg, M., Hudecz, O. Buschhorn, B. A., Bulkescher, J. Conrad, C., Comartin, D., Schleiffer A., Sarov, M., Pozniakovsky, A., Slabicki, M. M., Schloissnig, S., Steinmacher, I., Leuschner, M., Ssykor, A., Lawo, S., Pelletier, L., Stark, H., Nasmyth, K., Ellenberg, J., Durbin, R. Buchholz, F., Mechtler, K., Hyman, A. A., and Peters, J. M. (2010) Systematic analysis of human protein complexes identifies chromosome segregation proteins. Science 328, 593-599.

Inoue, T., Hiratsuka, M., Osaki, M., Yamada, H., Kishimoto, I., Yamaguchi, S., Nakano, S., Katoh, M., Ito, H., and Oshimura, M. (2007). SIRT2, a tubulin deacetylase, acts to block the entry to chromosome condensation in response to mitotic stress. Oncogene 26, 945-957.

Irniger, S., and Nasmyth, K. (1997). The anaphase-promoting complex is required in G1 arrested yeast cells to inhibit B-type cyclin accumulation and to prevent uncontrolled entry into S-phase. J. Cell Sci. 110 1523-1531.

Jackson, P. K. (2006). Developmental neurobiology: a destructive switch for neurons. Nature 442, 365-366.

Ji, M., Li, H., Suh, H. C., Klarmann, K. D., Yokota, Y., and Keller, J. R. (2008). Id2 intrinsically regulates lymphoid and erythroid development via interaction with different target proteins. Blood 112 1068-1077.

Ji, P., Jiang, H., Rekhtman, K., Bloom, J., Ichetovkin, M., Pagano, M., and Zhu, L. (2004). An Rb-Skp2-p27 pathway mediates acute cell cycle inhibition by $\mathrm{Rb}$ and is retained in a partialpenetrance Rb mutant. Mol. Cell 16, 47-58.
Jiang, L., Huang, C. G., Lu, Y. C. Luo, C., Hu, G. H., Liu, H. M. Chen, J. X., and Han, H. X. (2008). Expression of ubiquitin-conjugating enzyme E2C/UbcH10 in astrocytic tumors. Brain Res. 1201, 161-166.

Johnstone, R. W., and Licht, J. D. (2003). Histone deacetylase inhibitors in cancer therapy: is transcription the primary target? Cancer Cell 4, 13-18.

Jung, S., Park, R. H., Kim, S., Jeon, Y. J., Ham, D. S., Jung, M. Y., Kim, S. S., Lee, Y. D., Park, C. H., and SuhKim, H. (2010). Id proteins facilitate self-renewal and proliferation of neural stem cells. Stem Cells Dev. 19, 831-841.

Justilien, V., and Fields, A. P. (2009). Ect2 links the PKCiota-Par6alpha complex to Racl activation and cellular transformation. Oncogene 28, 3597-3607.

Justilien, V., Jameison, L., Der, C. J., Rossman, K. L., and Fields, A. P. (2011). Oncogenic activity of Ect2 is regulated through protein kinase C iota-mediated phosphorylation. J. Biol. Chem. 286, 8149-8157.

Kawakami, M., and Nakayama, J. (1997). Enhanced expression of prostate-specific membrane antigen gene in prostate cancer as revealed by in situ hybridization. Cancer Res. 57, 2321-2324.

Kawamoto, H., Wada, H., and Katsura, Y. (2010). A revised scheme for developmental pathways of hematopoietic cells: the myeloid-based model. Int. Immunol. 22, 65-70.

Ke, P. Y., Kuo, Y. Y., Hu, C. M., and Chang, Z. F. (2005). Control of dTTP pool size by anaphase promoting complex/cyclosome is essential for the maintenance of genetic stability. Genes Dev. 19, 1920-1933.

Kim, H. S., Vassilopoulos, A., Wang, R. H., Lahusen, T., Xiao, Z., Xu, X., Li, C., Veenstra, T. D., Li, B., Yu, H., Ji, J., Wang, X. W., Park, S. H., Cha, Y. I., Gius, D., and Deng, C. X. (2011). SIRT2 maintains genome integrity and suppresses tumorigenesis through regulating APC/C activity. Cancer Cell 20, 487-499.

Kim, S., and Yu, H. (2011). Mutual regulation between the spindle checkpoint and APC/C. Semin. Cell Dev. Biol. 22, 551-558.

Kimata, Y., Matsuyama, A., Nagao, K., Furuya, K., Obuse, C., Yoshida, M., and Yanagida, M. (2008). Diminishing HDACs by drugs or mutations promotes normal or abnormal sister chromatid separation by affecting APC/C and adherin. J. Cell Sci. 121, 1107-1118.

Kitajima, S., Kudo, Y., Ogawa, I., Tatsuka, M., Kawai, H., Pagano, M., and 
Takata, T. (2007). Constitutive phosphorylation of aurora-a on ser51 induces its stabilization and consequent overexpression in cancer. PLoS ONE 2, e944. doi:10.1371/journal.pone.0000944

Knecht, R., Elez, R., Oechler, M., Solbach, C., von Ilberg, C., and Strebhardt, K. (1999). Prognostic significance of polo-like kinase (PLK) expression in squamous cell carcinomas of the head and neck. Cancer Res. 59, 2794-2797.

Koga, H., Harada, M., Ohtsubo, M., Shishido, S., Kumemura, H., Hanada, S., Taniguchi, E., Yamashita, K., Kumashiro, R., Ueno, T., and Sata, M. (2003). Troglitazone induces p27Kip1-associated cell-cycle arrest through down-regulating Skp2 in human hepatoma cells. Hepatology 37, 1086-1096.

Kops, G. J., Van Der Voet, M., Manak, M. S., Van Osch, M. H., Naini, S. M., Brear, A., Mcleod, I. X., Hentschel, D. M., Yates, J. R. III, Van Den Heuvel, S., and Shah, J. V. (2010). APC16 is a conserved subunit of the anaphase-promoting complex/cyclosome. J. Cell Sci. 123, 1623-1633.

Kotani, S., Tugendreich, S., Fujii, M., Jorgensen, P. M., Watanabe, N., Hoog, C., Hieter, P., and Todokoro, K. (1998). PKA and MPF-activated polo-like kinase regulate anaphasepromoting complex activity and mitosis progression. Mol. Cell 1, 371-380.

Koul, D., Jasser, S. A., Lu, Y., Davies, M. A., Shen, R., Shi, Y., Mills, G. B., and Yung, W. K. A. (2002a), Motif analysis of the tumor suppressor gene MMAC/PTEN identifies tyrosines critical for tumor suppression and lipid phosphatase activity. Oncogene 21, 2357-2364.

Koul, D., Shen, R., Garyali, A., Ke, L. D., Liu, T. J., and Yung, W. K. (2002b). MMAC/PTEN tumor suppressor gene regulates vascular endothelial growth factor-mediated angiogenesis in prostate cancer. Int. J. Oncol. 21, 469-475.

Kouzarides, T. (1999). Histone acetylases and deacetylases in cell proliferation. Curr. Opin. Genet. Dev. 9, 40-48.

Kowanetz, M., Valcourt, U., Bergstrom, R., Heldin, C. H., and Moustakas, A. (2004). Id 2 and Id 3 define the potency of cell proliferation and differentiation responses to transforming growth factor beta and bone morphogenetic protein. Mol. Cell. Biol. 24, 4241-4254.

Kuo, M. H., and Allis, C. D. (1998). Roles of histone acetyltransferases and deacetylases in gene regulation. Bioessays 20, 615-626.

Kwon, C. H., Zhao, D., Chen, J., Alcantara, S., Li, Y., Burns, D. K., Mason, R. P., Lee, E. Y., Wu, H., and Parada, L. F. (2008). Pten haploinsufficiency accelerates formation of high-grade astrocytomas. Cancer Res. 68, 32863294.

Lagger, G., O'Carroll, D., Rembold, M., Khier, H., Tischler, J., Weitzer, G., Schuettengruber, B., Hauser, C., Brunmeir, R., Jenuwein, T., and Seiser, C. (2002). Essential function of histone deacetylase 1 in proliferation control and CDK inhibitor repression. EMBO J. 21, 2672-2681.

Lane, H. A., and Nigg, E. A. (1996). Antibody microinjection reveals an essential role for human polo-like kinase 1 (Plk1) in the functional maturation of mitotic centrosomes. J. Cell Biol. 135, 1701-1713.

Lasorella, A., Boldrini, R., Dominici, C., Donfrancesco, A., Yokota, Y., Inserra, A., and Iavarone, A. (2002). Id2 is critical for cellular proliferation and is the oncogenic effector of N-myc in human neuroblastoma. Cancer Res. $62,301-306$.

Lasorella, A., and Iavarone, A. (2006). The protein ENH is a cytoplasmic sequestration factor for Id2 in normal and tumor cells from the nervous system. Proc. Natl. Acad. Sci. U.S.A. 103, 4976-4981.

Lee, J. O., Yang, H., Georgescu, M. M., Di Cristofano, A., Maehama, T., Shi, Y., Dixon, J. E., Pandolfi, P., and Pavletich, N. P. (1999). Crystal structure of the PTEN tumor suppressor: implications for its phosphoinositide phosphatase activity and membrane association. Cell 99, 323-334.

Lehman, N. L., Verschuren, E. W., Hsu, J. Y., Cherry, A. M., and Jackson, P. K. (2006). Overexpression of the anaphase promoting complex/cyclosome inhibitor Emil leads to tetraploidy and genomic instability of p53-deficient cells. Cell Cycle 5, 1569-1573.

Leverson, J. D., Joazeiro, C. A., Page, A. M., Huang, H., Hieter, P., and Hunter, T. (2000). The APC11 RING-H2 finger mediates E2-dependent ubiquitination. Mol. Biol. Cell 11, 2315-2325.

Li, D. M., and Sun, H. (1998). PTEN/MMAC1/TEP1 suppresses the tumorigenicity and induces G1 cell cycle arrest in human glioblastoma cells. Proc. Natl. Acad. Sci. U.S.A. 95, 15406-15411.

Li, J., Yen, C., Liaw, D., Podsypanina, K., Bose, S., Wang, S. I., Puc, J., Miliaresis, C., Rodgers, L., McCombie, R., Bigner, S. H., Giovanella,
B. C., Ittmann, M., Tycko, B., Hibshoosh, H., Wigler, M. H., and Parsons, R. (1997). PTEN, a putative protein tyrosine phosphatase gene mutated in human brain, breast, and prostate cancer. Science 275, 1943-1947.

Li, M., Shin, Y. H., Hou, L., Huang, X., Wei, Z., Klann, E., and Zhang, P. (2008). The adaptor protein of the anaphase promoting complex $\mathrm{Cdh} 1$ is essential in maintaining replicative lifespan and in learning and memory. Nat. Cell Biol. 10, 1083-1089.

Li, W., Wu, G., and Wan, Y. (2007). The dual effects of Cdh1/APC in myogenesis. FASEB J. 21, 3606-3617.

Li, X., Tang, X., Jablonska, B., Aguirre, A., Gallo, V., and Luskin, M. B. (2009). p27(KIP1) regulates neurogenesis in the rostral migratory stream and olfactory bulb of the postnatal mouse. J. Neurosci. 29 , 2902-2914.

Lim, M. S., Adamson, A., Lin, Z., PerezOrdonez, B., Jordan, R. C., Tripp, S., Perkins, S. L., and ElenitobaJohnson, K. S. (2002). Expression of Skp2, a p27(Kip1) ubiquitin ligase in malignant lymphoma: correlation with p27(Kip1) and proliferation index. Blood 100, 2950-2956.

Lin, H. K., Wang, G., Chen, Z., TeruyaFeldstein, J., Liu, Y., Chan, C. H. Yang, W. L., Erdjument-Bromage, H., Nakayama, K. I., Nimer, S. Tempst, P., and Pandolfi, P. P. (2009). Phosphorylation-dependent regulation of cytosolic localization and oncogenic function of Skp2 by Akt/PKB. Nat. Cell Biol. 11, 420-432.

Lin, R., Wang, T. T., Miller, W. H. Jr., and White, J. H. (2003). Inhibition of F-box protein p45(SKP2) expression and stabilization of cyclin-dependent kinase inhibitor p27(KIP1) in vitamin D analogtreated cancer cells. Endocrinology 144, 749-753.

Lindon, C., and Pines, J. (2004). Ordered proteolysis in anaphase inactivates Plk1 to contribute to proper mitotic exit in human cells. J. Cell Biol. 164, 233-241.

Liot, C., Seguin, L., Siret, A., Crouin, C. Schmidt, S., and Bertoglio, J. (2011). $\mathrm{APC}(\mathrm{cdh} 1)$ mediates degradation of the oncogenic rho-GEF Ect2 after mitosis. PLoS ONE 6, e23676. doi:10.1371/journal.pone.0023676

Lipkowitz, S., and Weissman, A. M. (2011). RINGs of good and evil: RING finger ubiquitin ligases at the crossroads of tumour suppression and oncogenesis. Nat. Rev. Cancer 11, 629-643.
Listovsky, T., Oren, Y. S., Yudkovsky, Y., Mahbubani, H. M., Weiss, A. M., Lebendiker, M., and Brandeis, M. (2004). Mammalian Cdh1/Fzr mediates its own degradation. EMBO J. 23, 1619-1626.

Liu, H., Moy, P., Kim, S., Xia, Y., Rajasekaran, A., Navarro, V., Knudsen, B., and Bander, N. H. (1997). Monoclonal antibodies to the extracellular domain of prostate-specific membrane antigen also react with tumor vascular endothelium. Cancer Res. 57, 3629-3634.

Liu, H. S., Ke, C. S., Cheng, H. C., Huang, C. Y., and Su, C. L. (2011a) Curcumin-induced mitotic spindle defect and cell cycle arrest in human bladder cancer cells occurs partly through inhibition of aurora A. Mol. Pharmacol. 80, 638-646.

Liu, X. S., Song, B., Elzey, B. D., Ratliff, T. L., Konieczny, S. F., Cheng, L. Ahmad, N., and Liu, X. (2011b). Polo-like kinase 1 facilitates loss of pten tumor suppressor-induced prostate cancer formation. J. Biol. Chem. 286, 35795-35800.

Liu, X., and Erikson, R. L. (2003). Pololike kinase (plk)1 depletion induces apoptosis in cancer cells. Proc. Natl. Acad. Sci. U.S.A. 100, 5789-5794.

Lopez-Bergami, P., Huang, C., Goydos, J. S., Yip, D., Bar-Eli, M., Herlyn, M., Smalley, K. S., Mahale, A., Eroshkin, A., Aaronson, S., and Ronai, Z. (2007). Rewired ERK-JNK signaling pathways in melanoma. Cancer Cell $11,447-460$.

Lu, M., Ma, J., Xue, W., Cheng, C., Wang, Y., Zhao, Y., Ke, Q., Liu, H., Liu, Y., Li, P., Cui, X., He, S., and Shen, A. (2009). The expression and prognosis of FOXO3a and Skp2 in human hepatocellular carcinoma. Pathol. Oncol. Res. 15, 679-687.

Lukas, C., Sorensen, C. S., Kramer, E., Santoni-Rugiu, E., Lindeneg, C., Peters, J. M., Bartek, J., and Lukas, J. (1999). Accumulation of cyclin B1 requires E2F and cyclin-A-dependent rearrangement of the anaphasepromoting complex. Nature 401, 815-818.

Lukasiewicz, K. B., Greenwood, T. M., Negron, V. C., Bruzek, A. K., Salisbury, J. L., and Lingle, W. L. (2011). Control of centrin stability by aurora A. PLoS ONE 6, e21291. doi:10.1371/journal.pone.0021291

Luu, T. H., Morgan, R. J., Leong, L., Lim, D., McNamara, M., Portnow, J., Frankel, P., Smith, D. D., Doroshow, J. H., Wong, C., Aparicio, A., Gandara, D. R., and Somlo, G. (2008). A phase II trial of vorinostat 
(suberoylanilide hydroxamic acid) in metastatic breast cancer: a California cancer consortium study. Clin. Cancer Res. 14, 7138-7142.

Macmillan, J. C., Hudson, J. W., Bull, S., Dennis, J. W., and Swallow, C. J. (2001). Comparative expression of the mitotic regulators SAK and PLK in colorectal cancer. Ann. Surg. Oncol. 8, 729-740.

Madoux, F., Simanski, S., Chase, P., Mishra, J. K., Roush, W. R., Ayad, N. G., and Hodder, P. (2010). An ultrahigh throughput cell-based screen for weel degradation inhibitors. J. Biomol. Screen. 15, 907-917.

Maehama, T., and Dixon, J. E. (1998). The tumor suppressor, PTEN/MMAC1, dephosphorylates the lipid second messenger, phosphatidylinositol 3,4,5trisphosphate. J. Biol. Chem. 273, 13375-13378.

Maier, D., Jones, G., Li, X., Schonthal, A. H., Gratzl, O., Van Meir, E. G., and Merlo, A. (1999). The PTEN lipid phosphatase domain is not required to inhibit invasion of glioma cells. Cancer Res. 59, 5479-5482.

Mamely, I., van Vugt, M. A., Smits, V. A., Semple, J. I., Lemmens, B., Perrakis, A., Medema, R. H., and Freire, R. (2006). Polo-like kinase-1 controls proteasome-dependent degradation of claspin during checkpoint recovery. Curr. Biol. 16, 1950-1955.

Manchado, E., Guillamot, M., de Carcer, G., Eguren, M., Trickey, M., Garcia-Higuera, I., Moreno, S., Yamano, H., Canamero, M., and Malumbres, M. (2010). Targeting mitotic exit leads to tumor regression in vivo: modulation by Cdk1, mastl, and the PP2A/B55alpha,delta phosphatase. Cancer Cell 18, 641-654.

Margottin-Goguet, F., Hsu, J. Y., Loktev, A., Hsieh, H. M., Reimann, J. D., and Jackson, P. K. (2003). Prophase destruction of Emil by the $\mathrm{SCF}$ (betaTrCP/Slimb) ubiquitin ligase activates the anaphase promoting complex to allow progression beyond prometaphase. Dev. Cell 4, 813-826.

Marino, S., Krimpenfort, P., Leung, C., van der Korput, H. A., Trapman, J., Camenisch, I., Berns, A., and Brandner, S. (2002). PTEN is essential for cell migration but not for fate determination and tumourigenesis in the cerebellum. Development 129, 3513-3522.

Marks, P., Rifkind, R. A., Richon, V. M., Breslow, R., Miller, T., and Kelly, W. K. (2001). Histone deacetylases and cancer: causes and therapies. Nat. Rev. Cancer 1, 194-202.
Marx, M., Lebuhotel, C., Laugier, D., Chapelle, A., Calothy, G., and Saule, S. (2010). Down regulation of $\mathrm{pRb}$ in cultures of avian neuroretina cells promotes proliferation of reactive Muller-like cells and emergence of retinal stem/progenitors. Exp. Eye Res. 90, 791-801.

McCubrey, J. A., Steelman, L. S., Kempf, C. R., Chappell, W. H., Abrams, S. L., Stivala, F., Malaponte, G., Nicoletti, F., Libra, M., Bäsecke, J., Maksimovic-Ivanic, D., Mijatovic, S., Montalto, G., Cervello, M., Cocco, L., and Martelli, A. M. (2011). Therapeutic resistance resulting from mutations in Raf/MEK/ERK and PI3K/PTEN/Akt/mTOR signaling pathways. J. Cell. Physiol. 226, 2762-2781.

McGarry, T. J., and Kirschner, M. W. (1998). Geminin, an inhibitor of DNA replication, is degraded during mitosis. Cell 93, 1043-1053.

Meraldi, P., Lukas, J., Fry, A. M., Bartek, J., and Nigg, E. A. (1999). Centrosome duplication in mammalian somatic cells requires E2F and Cdk2cyclin A. Nat. Cell Biol. 1, 88-93.

Miller, J. J., Summers, M. K., Hansen, D. V., Nachury, M. V., Lehman, N. L., Loktev, A., and Jackson, P. K. (2006). Emil stably binds and inhibits the anaphase-promoting complex/cyclosome as a pseudosubstrate inhibitor. Genes Dev. 20, 2410-2420.

Miyoshi, Y., Iwao, K., Egawa, C., and Noguchi, S. (2001). Association of centrosomal kinase STK15/BTAK mRNA expression with chromosomal instability in human breast cancers. Int. J. Cancer 92, 370-373.

Modesitt, S. C., Sill, M., Hoffman, J. S., Bender, D. P., and Gynecologic Oncology Group. (2008). A phase II study of vorinostat in the treatment of persistent or recurrent epithelial ovarian or primary peritoneal carcinoma: a gynecologic oncology group study. Gynecol. Oncol. 109, 182-186.

Mondal, G., Sengupta, S., Panda, C. K., Gollin, S. M., Saunders, W. S., and Roychoudhury, S. (2007). Overexpression of Cdc20 leads to impairment of the spindle assembly checkpoint and aneuploidization in oral cancer. Carcinogenesis 28, 81-92.

Montagnoli, A., Fiore, F., Eytan, E., Carrano, A. C., Draetta, G. F., Hershko, A., and Pagano, M. (1999). Ubiquitination of p27 is regulated by cdk-dependent phosphorylation and trimeric complex formation. Genes Dev. 13, 1181-1189.

Nakamura, Y., Ozaki, T., Koseki, H., Nakagawara, A., and Sakiyama, S. (2003). Accumulation of p27 KIP1 is associated with BMP2-induced growth arrest and neuronal differentiation of human neuroblastomaderived cell lines. Biochem. Biophys. Res. Commun. 307, 206-213.

Nakayama, J., Xiao, G., Noma, K., Malikzay, A., Bjerling, P., Ekwall, K., Kobayashi, R., and Grewal, S. I. (2003). Alp13, an MRG family protein, is a component of fission yeast Clr6 histone deacetylase required for genomic integrity. $E M B O ~ J .22$, 2776-2787.

Nguyen, L., Besson, A., Heng, J. I., Schuurmans, C., Teboul, L., Parras, C., Philpott, A., Roberts, J. M., and Guillemot, F. (2007). p27Kip1 independently promotes neuronal differentiation and migration in the cerebral cortex. Bull. Mem. Acad. R. Med. Belg. 162, 310-314.

Nguyen, L., Besson, A., Roberts, J. M. and Guillemot, F. (2006). Coupling cell cycle exit, neuronal differentiation and migration in cortical neurogenesis. Cell Cycle 5, 2314-2318.

Nilsson, J. (2011). Cdc20 control of cell fate during prolonged mitotic arrest: do Cdc20 protein levels affect cell fate in response to antimitotic compounds? Bioessays 33, 903-909.

Nilsson, J., Yekezare, M., Minshull, J. and Pines, J. (2008). The APC/C maintains the spindle assembly checkpoint by targeting $\mathrm{Cdc} 20$ for destruction. Nat. Cell Biol. 10, 1411-1420.

Noh, E. J., and Lee, J. S. (2003). Functional interplay between modulation of histone deacetylase activity and its regulatory role in G2-M transition. Biochem. Biophys. Res. Commun. 310, 267-273.

North, B. J., Marshall, B. L., Borra, M. T., Denu, J. M., and Verdin, E. (2003). The human Sir2 ortholog, SIRT2, is an NAD+-dependent tubulin deacetylase. Mol. Cell 11, 437-444.

North, B. J., and Verdin, E. (2007). Interphase nucleo-cytoplasmic shuttling and localization of SIRT2 during mitosis. PLoS ONE 2, e784. doi:10.1371/journal.pone.0000784

Ohkura, H., Hagan, I. M., and Glover, D. M. (1995). The conserved schizosaccharomyces pombe kinase plo1, required to form a bipolar spindle, the actin ring, and septum, can drive septum formation in G1 and G2 cells. Genes Dev. 9, 1059-1073.

Okamoto, Y., Ozaki, T., Miyazaki, K., Aoyama, M., Miyazaki, M., and Nakagawara, A. (2003). UbcH10 is the cancer-related E2 ubiquitinconjugating enzyme. Cancer Res. 63, 4167-4173.
Olsson, T. G., Silverstein, R. A., Ekwall, K., and Sunnerhagen, P. (1999). Transient inhibition of histone deacetylase activity overcomes silencing in the mating-type region in fission yeast. Curr. Genet. 35, 82-87.

Pallante, P., Berlingieri, M. T., Troncone, G., Kruhoffer, M., Orntoft, T. F., Viglietto, G., Caleo, A., Migliaccio, I., Decaussin-Petrucci, M., Santoro, M., Palombini, L., and Fusco, A. (2005). UbcH10 overexpression may represent a marker of anaplastic thyroid carcinomas. Br. J. Cancer 93, 464-471.

Pan, J., and Chen, R. H. (2004). Spindle checkpoint regulates Cdc20p stability in Saccharomyces cerevisiae. Genes Dev. 18, 1439-1451.

Passmore, L. A., Booth, C. R., VenienBryan, C., Ludtke, S. J., Fioretto, C., Johnson, L. N., Chiu, W., and Barford, D. (2005). Structural analysis of the anaphase-promoting complex reveals multiple active sites and insights into polyubiquitylation. Mol. Cell 20, 855-866.

Payne, D. M., Rossomando, A. J., Martino, P., Erickson, A. K., Her J. H., Shabanowitz, J., Hunt, D. F., Weber, M. J., and Sturgill, T. W. (1991). Identification of the regulatory phosphorylation sites in $\mathrm{pp} 42 /$ mitogen-activated protein kinase (MAP kinase). EMBO J. 10, 885-892.

Perk, J., Iavarone, A., and Benezra, R. (2005). Id family of helix-loop-helix proteins in cancer. Nat. Rev. Cancer 5, 603-614.

Perry, S. S., Zhao, Y., Nie, L., Cochrane, S. W., Huang, Z., and Sun, X. H. (2007). Id1, but not Id3, directs long-term repopulating hematopoietic stem-cell maintenance. Blood 110, 2351-2360.

Petersen, B. O., Wagener, C., Marinoni, F., Kramer, E. R., Melixetian, M., Lazzerini Denchi, E., Gieffers, C., Matteucci, C., Peters, J. M., and Helin, K. (2000). Cell cycleand cell growth-regulated proteolysis of mammalian CDC6 is dependent on APC-CDH1. Genes Dev. 14, 2330-2343.

Pfleger, C. M., and Kirschner, M. W. (2000). The KEN box: an APC recognition signal distinct from the $\mathrm{D}$ box targeted by Cdh1. Genes Dev. 14, 655-665.

Pihan, G. A., Purohit, A., Wallace, J., Malhotra, R., Liotta, L., and Doxsey, S. J. (2001). Centrosome defects can account for cellular and genetic changes that characterize prostate cancer progression. Cancer Res. 61, 2212-2219. 
Pines, J. (2011). Cubism and the cell cycle: the many faces of the APC/C. Nat. Rev. Mol. Cell Biol. 12, 427-438. Podsypanina, K., Ellenson, L. H., Nemes, A., Gu, J., Tamura, M., Yamada, K. M., Cordon-Cardo, C., Catoretti, G., Fisher, P. E., and Parsons, R. (1999). Mutation of Pten/Mmacl in mice causes neoplasia in multiple organ systems. Proc. Natl. Acad. Sci. U.S.A. 96, 1563-1568.

Potapova, O., Gorospe, M., Bost, F., Dean, N. M., Gaarde, W. A., Mercola, D., and Holbrook, N. J. (2000). c-jun $\mathrm{N}$-terminal kinase is essential for growth of human T98G glioblastoma cells. J. Biol. Chem. 275, 24767-24775.

Pray, T. R., Parlati, F., Huang, J., Wong, B. R., Payan, D. G., Bennett, M. K., Issakani, S. D., Molineaux, S., and Demo, S. D. (2002). Cell cycle regulatory E3 ubiquitin ligases as anticancer targets. Drug Resist. Updat. 5, 249-258.

Qian, Y. W., Erikson, E., Li, C., and Maller, J. L. (1998). Activated pololike kinase Plx1 is required at multiple points during mitosis in Xenopus laevis. Mol. Cell. Biol. 18, 4262-4271.

Qiao, X., Zhang, L., Gamper, A. M., Fujita, T., and Wan, Y. (2010). APC/C-Cdh1: from cell cycle to cellular differentiation and genomic integrity. Cell Cycle 9, 3904-3912.

Radke, S., Pirkmaier, A., and Germain, D. (2005). Differential expression of the F-box proteins Skp2 and Skp2B in breast cancer. Oncogene 24, 3448-3458.

Rajasekaran, A. K., Anilkumar, G., and Christiansen, J. J. (2005). Is prostatespecific membrane antigen a multifunctional protein? Am. J. Physiol. Cell Physiol. 288, C975-C981.

Rajasekaran, S. A., Christiansen, J. J., Schmid, I., Oshima, E., Ryazantsev, S., Sakamoto, K., Weinstein, J., Rao, N. P., and Rajasekaran, A. K. (2008). Prostate-specific membrane antigen associates with anaphase-promoting complex and induces chromosomal instability. Mol. Cancer Ther. 7 , 2142-2151.

Rape, M., and Kirschner, M. W. (2004). Autonomous regulation of the anaphase-promoting complex couples mitosis to S-phase entry. Nature 432, 588-595.

Rape, M., Reddy, S. K., and Kirschner, M. W. (2006). The processivity of multiubiquitination by the APC determines the order of substrate degradation. Cell 124, 89-103.

Reed, S. I. (2008). Deathproof: new insights on the role of skp2 in tumorigenesis. Cancer Cell 13, 88-89.

Reimann, J. D., Freed, E., Hsu, J. Y., Kramer, E. R., Peters, J. M., and Jackson, P. K. (2001). Emil is a mitotic regulator that interacts with $\mathrm{Cdc} 20$ and inhibits the anaphase promoting complex. Cell 105, 645-655.

Reynisdottir, I., Polyak, K., Iavarone, A., and Massague, J. (1995). Kip/Cip and Ink $4 \mathrm{cdk}$ inhibitors cooperate to induce cell cycle arrest in response to TGF-beta. Genes Dev. 9, 1831-1845.

Rose, A. E., Wang, G., Hanniford, D., Monni, S., Tu, T., Shapiro, R. L., Berman, R. S., Pavlick, A. C., Pagano, M., Darvishian, F., Mazumdar, M., Hernando, E., and Osman, I. (2011). Clinical relevance of SKP2 alterations in metastatic melanoma. Pigment Cell Melanoma Res. 24, 197-206.

Ross, J. S., Sheehan, C. E., Fisher, H. A., Kaufman, R. P. Jr, Kaur, P., Gray, K., Webb, I., Gray, G. S., Mosher, R., and Kallakury, B. V. (2003). Correlation of primary tumor prostate-specific membrane antigen expression with disease recurrence in prostate cancer. Clin. Cancer Res. 9, 6357-6362.

Ross, K. E., and Cohen-Fix, O. (2003). The role of Cdhlp in maintaining genomic stability in budding yeast. Genetics 165, 489-503.

Rothschild, G., Zhao, X., Iavarone, A., and Lasorella, A. (2006). E proteins and Id 2 converge on p57Kip2 to regulate cell cycle in neural cells. Mol. Cell. Biol. 26, 4351-4361.

Sabado Alvarez, C. (2008). Molecular biology of retinoblastoma. Clin. Transl. Oncol. 10, 389-394.

Salhia, B., Tran, N. L., Chan, A., Wolf, A., Nakada, M., Rutka, F., Ennis, M., McDonough, W. S., Berens, M. E., Symons, M., and Rutka, J. T. (2008). The guanine nucleotide exchange factors trio, Ect2, and Vav3 mediate the invasive behavior of glioblastoma. Am. J. Pathol. 173, 1828-1838.

Sano, M., Genkai, N., Yajima, N., Tsuchiya, N., Homma, J., Tanaka, R., Miki, T., and Yamanaka, R. (2006). Expression level of ECT2 protooncogene correlates with prognosis in glioma patients. Oncol. Rep. 16, 1093-1098.

Saunders, L. R., and Verdin, E. (2007). Sirtuins: critical regulators at the crossroads between cancer and aging. Oncogene 26, 5489-5504.

Schöffski, P. (2009). Polo-like kinase (PLK) inhibitors in preclinical and early clinical development in oncology. Oncologist 14, 559-570.

Schreiber, A., Stengel, F., Zhang, Z., Enchev, R. I., Kong, E. H., Morris, E. P., Robinson, C. V., da Fonseca, P. C., and Barford, D. (2011). Structural basis for the subunit assembly of the anaphase-promoting complex. Nature 470, 227-232.

Schuler, S., Diersch, S., Hamacher, R., Schmid, R. M., Saur, D., and Schneider, G. (2011). SKP2 confers resistance of pancreatic cancer cells towards TRAIL-induced apoptosis. Int. J. Oncol. 38, 219-225.

Schwickart, M., Havlis, J., Habermann, B., Bogdanova, A., Camasses, A. Oelschlaegel, T., Shevchenko, A., and Zachariae, W. (2004). Swm1/Apc13 is an evolutionarily conserved subunit of the anaphase-promoting complex stabilizing the association of Cdc16 and Cdc27. Mol. Cell. Biol. 24, 3562-3576.

Seguin, L., Liot, C., Mzali, R., Harada, R., Siret, A., Nepveu, A., and Bertoglio, J. (2009). CUX1 and E2F1 regulate coordinated expression of the mitotic complex genes Ect2, MgcRacGAP, and MKLP1 in S phase. Mol. Cell. Biol. 29, 570-581.

Sen, S., Zhou, H., Zhang, R. D., Yoon, D. S., Vakar-Lopez, F., Ito, S., Jiang, F., Johnston, D., Grossman, H. B. Ruifrok, A. C., Katz, R. L., Brinkley, W., and Czerniak, B. (2002). Amplification/overexpression of a mitotic kinase gene in human bladder cancer. J. Natl. Cancer Inst. 94 1320-1329.

Shomin, C. D., Restituyo, E., Cox, K. J., and Ghosh, I. (2011). Selection of cyclic-peptide inhibitors targeting aurora kinase A: problems and solutions. Bioorg. Med. Chem. 19, 6743-6749.

Silva, A., Yunes, J. A., Cardoso, B. A., Martins, L. R., Jotta, P. Y., Abecasis, M., Nowill, A. E., Leslie, N. R., Cardoso, A. A., and Barata, J. T. (2008). PTEN posttranslational inactivation and hyperactivation of the PI3K/Akt pathway sustain primary $\mathrm{T}$ cell leukemia viability. $J$. Clin. Invest. 118, 3762-3774.

Silver, D. A., Pellicer, I., Fair, W. R., Heston, W. D., and Cordon-Cardo, C. (1997). Prostate-specific membrane antigen expression in normal and malignant human tissues. Clin Cancer Res. 3, 81-85.

Silverstein, R. A., Richardson, W., Levin, H., Allshire, R., and Ekwall, K. (2003). A new role for the transcriptional corepressor SIN3; regulation of centromeres. Curr. Biol. 13, 68-72.

Song, M. S., Carracedo, A., Salmena, L., Song, S. J., Egia, A., Malumbres, M., and Pandolfi, P. P. (2011). Nuclear PTEN regulates the APC$\mathrm{CDH} 1$ tumor-suppressive complex in a phosphatase-independent manner. Cell 144, 187-199.
Sorensen, C. S., Lukas, C., Kramer, E. R., Peters, J. M., Bartek, J., and Lukas, J. (2000). Nonperiodic activity of the human anaphasepromoting complex-Cdh1 ubiquitin ligase results in continuous DNA synthesis uncoupled from mitosis. Mol. Cell. Biol. 20, 7613-7623.

Steck, P. A., Pershouse, M. A., Jasser, S. A., Yung, W. K., Lin, H., Ligon, A. H., Langford, L. A., Baumgard, M. L., Hattier, T., Davis, T., Frye, C., Hu, R., Swedlund, B., Teng, D. H., and Tavtigian, S. V. (1997). Identification of a candidate tumour suppressor gene, MMAC1, at chromosome $10 \mathrm{q} 23.3$ that is mutated in multiple advanced cancers. Nat. Genet. 15 , 356-362.

Stegmuller, J., and Bonni, A. (2005). Moving past proliferation: new roles for Cdh1-APC in postmitotic neurons. Trends Neurosci. 28, 596-601.

Strahl, B. D., and Allis, C. D. (2000). The language of covalent histone modifications. Nature 403, 41-45.

Strebhardt, K., Kneisel, L., Linhart, C., Bernd, A., and Kaufmann, R. (2000). Prognostic value of polo like kinase expression in melanomas. JAMA 283, 479-480.

Strebhardt, K., and Ullrich, A. (2006). Targeting polo-like kinase 1 for cancer therapy. Nat. Rev. Cancer 6, 321-330.

Summers, M. K., Pan, B., Mukhyala, K., and Jackson, P. K. (2008). The unique $\mathrm{N}$ terminus of the $\mathrm{UbcH} 10$ E2 enzyme controls the threshold for APC activation and enhances checkpoint regulation of the APC. Mol. Cell 31, 544-556.

Sweat, S. D., Pacelli, A., Murphy, G. P., and Bostwick, D. G. (1998). Prostate-specific membrane antigen expression is greatest in prostate adenocarcinoma and lymph node metastases. Urology 52, 637-640.

Taddei, A., Roche, D., Sibarita, J. B., Huart, S., Maison, C., Bailly, D., and Almouzni, G. (2001). Localizing Replication Sites and Nuclear Proteins. Mapping Protein/DNA Interactions by Cross-linking. Paris: Institut national de la sante et de la recherche medicale (INSERM).

Tamamori-Adachi, M., Hayashida, K., Nobori, K., Omizu, C., Yamada, K., Sakamoto, N., Kamura, T., Fukuda, K., Ogawa, S., Nakayama, K. I., and Kitajima, S. (2004). Down-regulation of p27Kip1 promotes cell proliferation of rat neonatal cardiomyocytes induced by nuclear expression of cyclin D1 and 
CDK4. evidence for impaired Skp2dependent degradation of $\mathrm{p} 27$ in terminal differentiation. J. Biol. Chem. 279, 50429-50436.

Tang, Z., Li, B., Bharadwaj, R., Zhu, H., Ozkan, E., Hakala, K., Deisenhofer, J., and Yu, H. (2001). APC2 cullin protein and APC11 RING protein comprise the minimal ubiquitin ligase module of the anaphasepromoting complex. Mol. Biol. Cell 12, 3839-3851.

Tarui, T., Takahashi, T., Nowakowski, R. S., Hayes, N. L., Bhide, P. G., and Caviness, V. S. (2005). Overexpression of p27 kip 1, probability of cell cycle exit, and laminar destination of neocortical neurons. Cereb. Cortex $15,1343-1355$

Thoma, C. R., Toso, A., Meraldi, P., and Krek, W. (2011). Mechanisms of aneuploidy and its suppression by tumour suppressor proteins. Swiss. Med. Wkly. 141, w13170.

Thornton, B. R., and Toczyski, D. P. (2006). Precise destruction: an emerging picture of the APC. Genes Dev. 20, 3069-3078.

Tribukait, B. (1991). DNA flow cytometry in carcinoma of the prostate for diagnosis, prognosis and study of tumor biology. Acta Oncol. 30, 187-192.

Trosko, J. E. (2009). Review paper: cancer stem cells and cancer nonstem cells: from adult stem cells or from reprogramming of differentiated somatic cells. Vet. Pathol. 46, 176-193.

Troyer, J. K., Beckett, M. L., and Wright, G. L. Jr. (1995). Detection and characterization of the prostate-specific membrane antigen (PSMA) in tissue extracts and body fluids. Int. J. Cancer 62, 552-558.

Tsuiki, H., Tnani, M., Okamoto, I., Kenyon, L. C., Emlet, D. R., HolgadoMadruga, M., Lanham, I. S., Joynes, C. J., Vo, K. T., and Wong, A. J. (2003). Constitutively active forms of c-jun $\mathrm{NH} 2$-terminal kinase are expressed in primary glial tumors. Cancer Res. 63, 250-255.

Tsvetkov, L. M., Yeh, K. H., Lee, S. J., Sun, H., and Zhang, H. (1999). p27(Kip1) ubiquitination and degradation is regulated by the SCF(Skp2) complex through phosphorylated Thr187 in p27. Curr. Biol. 9, 661-664.

Tury, A., Mairet-Coello, G., and DiCicco-Bloom, E. (2011). The cyclin-dependent kinase inhibitor p57Kip2 regulates cell cycle exit, differentiation, and migration of embryonic cerebral cortical precursors. Cereb. Cortex 21, 1840-1856.
Uddin, S., Hussain, A., Al-Hussein, K., Platanias, L. C., and Bhatia, K. G. (2004). Inhibition of phosphatidylinositol 3'-kinase induces preferentially killing of PTEN-null $\mathrm{T}$ leukemias through AKT pathway. Biochem. Biophys. Res. Commun. 320, 932-38.

van Ree, J. H., Jeganathan, K. B. Malureanu, L., and van Deursen, J. M. (2010). Overexpression of the E2 ubiquitin-conjugating enzyme UbcH10 causes chromosome missegregation and tumor formation. $J$ Cell Biol. 188, 83-100.

Vaquero, A., Scher, M. B., Lee, D. H., Sutton, A., Cheng, H. L., Alt, F. W., Serrano, L., Sternglanz, R., and Reinberg, D. (2006). SirT2 is a histone deacetylase with preference for histone H4 lys 16 during mitosis. Genes Dev. 20, 1256-1261.

Vernon, A. E., Devine, C., and Philpott, A. (2003). The cdk inhibitor p27Xicl is required for differentiation of primary neurones in Xenopus. Development 130, 85-92.

Vidal, A., and Koff, A. (2000). Cell-cycle inhibitors: three families united by a common cause. Gene 247, 1-15.

Visintin, R., Prinz, S., and Amon, A. (1997). CDC20 and CDH1: a family of substrate-specific activators of APC-dependent proteolysis. Science 278, 460-463.

Wai, D. H., Schaefer, K. L., Schramm, A., Korsching, E., Van Valen, F., Ozaki, T., Boecker, W., Schweigerer, L., Dockhorn-Dworniczak, B., and Poremba, C. (2002). Expression analysis of pediatric solid tumor cell lines using oligonucleotide microarrays. Int. J. Oncol. 20, 441-451.

Walker, S. M., Leslie, N. R., Perera, N. M., Batty, I. H., and Downes, C. P. (2004). The tumour-suppressor function of PTEN requires an $\mathrm{N}$-terminal lipid-binding motif. Biochem. J. 379, 301-307.

Wang, L. Y., and Kung, H. J. (2011). Male germ cell-associated kinase is overexpressed in prostate cancer cells and causes mitotic defects via deregulation of $\mathrm{APC} / \mathrm{C}(\mathrm{CDH} 1)$. Oncogene. doi: 10.1038/onc.2011.464. [Epub ahead of print].

Wang, Q., Moyret-Lalle, C., Couzon, F., Surbiguet-Clippe, C., Saurin, J. C., Lorca, T., Navarro, C., and Puisieux, A. (2003). Alterations of anaphasepromoting complex genes in human colon cancer cells. Oncogene 22, 1486-1490.

Wang, R. H., Sengupta, K., Li, C., Kim, H. S., Cao, L., Xiao, C., Kim, S., Xu, X., Zheng, Y., Chilton, B., Jia, R., Zheng, Z. M., Appella, E., Wang, X.
W., Ried, T., and Deng, C. X. (2008a) Impaired DNA damage response, genome instability, and tumorigenesis in SIRT1 mutant mice. Cancer Cell 14, 312-323.

Wang, R. H., Zheng, Y., Kim, H. S. $\mathrm{Xu}, \mathrm{X} .$, Cao, L., Luhasen, T., Lee, M. H., Xiao, C., Vassilopoulos, A. Chen, W., Gardner, K., Man, Y. G., Hung, M. C., Finkel, T., and Deng, C. X. (2008b). Interplay among BRCA1, SIRT1, and survivin during BRCA1-associated tumorigenesis. Mol. Cell 32 11-20.

Wang, X., and Dai, W. (2005). Shugoshin, a guardian for sister chromatid segregation. Exp. Cell Res. 310, 1-9.

Wasch, R., and Engelbert, D. (2005). Anaphase-promoting complexdependent proteolysis of cell cycle regulators and genomic instability of cancer cells. Oncogene 24 $1-10$.

Watanabe, N., Arai, H., Nishihara, Y., Taniguchi, M., Watanabe, N., Hunter, T., and Osada, H. (2004). M-phase kinases induce phospho-dependent ubiquitination of somatic Weel by SCFbeta-TrCP. Proc. Natl. Acad. Sci. U.S.A. 101, 4419-4424.

Wei, W., Ayad, N. G., Wan, Y., Zhang, G. J., Kirschner, M. W., and Kaelin, W. G. Jr. (2004). Degradation of the SCF component Skp2 in cellcycle phase G1 by the anaphasepromoting complex. Nature 428, 194-198.

Weichert, W., Schmidt, M., Gekeler, V., Denkert, C., Stephan, C., Jung, K., Loening, S., Dietel, M., and Kristiansen, G. (2004). Polo-like kinase 1 is overexpressed in prostate cancer and linked to higher tumor grades. Prostate 60, 240-245.

Westermann, F., Henrich, K. O. Wei, J. S., Lutz, W., Fischer, M., Konig, R., Wiedemeyer, R., Ehemann, V., Brors, B., Ernestus, K., Leuschner, I., Benner, A., Khan, J., and Schwab, M. (2007). High Skp2 expression characterizes high-risk neuroblastomas independent of MYCN status. Clin. Cancer Res. 13, 4695-4703.

Wickliffe, K. E., Lorenz, S., Wemmer, D. E., Kuriyan, J., and Rape, M. (2011a). The mechanism of linkagespecific ubiquitin chain elongation by a single-subunit E2. Cell 144, 769-781.

Wickliffe, K. E., Williamson, A., Meyer, H. J., Kelly, A., and Rape, M. (2011b). K11-linked ubiquitin chains as novel regulators of cell division. Trends Cell Biol. 21, 656-663.
Williamson, A., Wickliffe, K. E., Mellone, B. G., Song, L., Karpen, G. H., and Rape, M. (2009). Identification of a physiological E2 module for the human anaphase-promoting complex. Proc. Natl. Acad. Sci. U.S.A. 106, 18213-18218.

Wirth, K. G., Ricci, R., Gimenez-Abian, J. F., Taghybeeglu, S., Kudo, N. R., Jochum, W., Vasseur-Cognet, M. and Nasmyth, K. (2004). Loss of the anaphase-promoting complex in quiescent cells causes unscheduled hepatocyte proliferation. Genes Dev. $18,88-98$.

Wohlschlegel, J. A., Dwyer, B. T., Dhar, S. K., Cvetic, C., Walter, J. C., and Dutta, A. (2000). Inhibition of eukaryotic DNA replication by geminin binding to Cdt1. Science 290, 2309-2312.

Wolf, G., Elez, R., Doermer, A., Holtrich, U., Ackermann, H., Stutte, H. J., Altmannsberger, H. M., RübsamenWaigmann, H., and Strebhardt, K. (1997). Prognostic significance of polo-like kinase (PLK) expression in non-small cell lung cancer. Oncogene 14, 543-549.

Wolf, G., Hildenbrand, R., Schwar, C., Grobholz, R., Kaufmann, M., Stutte, H. J., Strebhardt, K., and Bleyl, U. (2000). Polo-like kinase: a novel marker of proliferation: correlation with estrogen-receptor expression in human breast cancer. Pathol. Res. Pract. 196, 753-759.

Wu, G., Glickstein, S., Liu, W., Fujita, T., Li, W., Yang, Q., Duvoisin, R., and Wan, Y. (2007). The anaphase-promoting complex coordinates initiation of lens differentiation. Mol. Biol. Cell 18, 1018-1029.

Wu, G., Qiu, X. L., Zhou, L., Zhu, J., Chamberlin, R., Lau, J., Chen, P. L., and Lee, W. H. (2008). Small molecule targeting the Hec1/Nek2 mitotic pathway suppresses tumor cell growth in culture and in animal. Cancer Res. 68 , 8393-8399.

Wu, T., Merbl, Y., Huo, Y., Gallop, J. L., Tzur, A., and Kirschner, M. W. (2010). UBE2S drives elongation of K11-linked ubiquitin chains by the anaphase-promoting complex. Proc. Natl. Acad. Sci. U.S.A. 107, 1355-1360.

Xia, H. H., He, H., De Wang, J., Gu, Q., Lin, M. C., Zou, B., Yu, L. F., Sun, Y. W., Chan, A. O., Kung, H. F., and Wong, B. C. (2006). Induction of apoptosis and cell cycle arrest by a specific c-jun $\mathrm{NH} 2$-terminal kinase (JNK) inhibitor, SP-600125, in gastrointestinal cancers. Cancer Lett. 241, 268-274. 
Xia, L., Robinson, D., Ma, A. H., Chen, H. C., Wu, F., Qiu, Y., and Kung, H. J. (2002). Identification of human male germ cell-associated kinase, a kinase transcriptionally activated by androgen in prostate cancer cells. J. Biol. Chem. 277, 35422-35433.

Xu, W. J., Zhang, S., Yang, Y., Zhang, N., Wang, W., Liu, S. Y., Tian, H. W., Dai, L., Xie, Q., Zhao, X., Wei, Y. Q., and Deng, H. X. (2011). Efficient inhibition of human colorectal carcinoma growth by RNA interference targeting polo-like kinase 1 in vitro and in vivo. Cancer Biother. Radiopharm. 26, 427-436.

Yang, G., Ayala, G., De Marzo, A., Tian, W., Frolov, A., Wheeler, T. M., Thompson, T. C., and Harper, J. W. (2002). Elevated Skp2 protein expression in human prostate cancer: association with loss of the cyclin-dependent kinase inhibitor p27 and PTEN and with reduced recurrence-free survival. Clin. Cancer Res. 8, 3419-3426.

Yang, Y. M., Bost, F., Charbono, W., Dean, N., McKay, R., Rhim, J. S., Depatie, C., and Mercola, D. (2003). C-jun $\mathrm{NH}(2)$-terminal kinase mediates proliferation and tumor growth of human prostate carcinoma. Clin. Cancer Res. 9, 391-401.

Yao, W., Qian, W., Zhu, C., Gui, L., Qiu, J., and Zhang, C. (2010). Cdh1-APC is involved in the differentiation of neural stem cells into neurons. $\mathrm{Neu}$ roreport 21, 39-44.

Ye, Y., and Rape, M. (2009). Building ubiquitin chains: E2 enzymes at work. Nat. Rev. Mol. Cell Biol. 10, 755-764.

Yokoi, S., Yasui, K., Iizasa, T., Takahashi, T., Fujisawa, T., and Inazawa,
J. (2003). Down-regulation of SKP2 induces apoptosis in lung-cancer cells. Cancer Sci. 94, 344-349.

Yokota, Y. (2001). Id and development. Oncogene 20, 8290-8298.

Yoon, H. E., Kim, S. A., Choi, H. S., Ahn, M. Y., Yoon, J. H., and Ahn, S. G. (2011). Inhibition of Plk1 and Pin 1 by $5^{\prime}$-nitroindirubinoxime suppresses human lung cancer cells. Cancer Lett. doi: 10.1016/j.canlet.2011.10.029. [Epub ahead of print].

Yoshida, M., Shimazu, T., and Matsuyama, A. (2003). Protein deacetylases: enzymes with functional diversity as novel therapeutic targets. Prog. Cell Cycle Res. 5, 269-278.

Yu, Z. K., Gervais, J. L., and Zhang, H. (1998). Human CUL-1 associates with the SKP1/SKP2 complex and regulates $\mathrm{p} 21$ (CIP1/WAF1) and cyclin D proteins. Proc. Natl. Acad. Sci. U.S.A. 95, 11324-11329.

Yuan, B., Xu, Y., Woo, J. H., Wang, Y., Bae, Y. K., Yoon, D. S., Wersto, R. P., Tully, E., Wilsbach, K., and Gabrielson, E. (2006). Increased expression of mitotic checkpoint genes in breast cancer cells with chromosomal instability. Clin. Cancer Res. 12, 405-410.

Zachariae, W., and Nasmyth, K. (1999). Whose end is destruction: cell division and the anaphase-promoting complex. Genes Dev. 13, 2039-2058.

Zeng, X., Sigoillot, F., Gaur, S., Choi, S., Pfaff, K. L., Oh, D. C., Hathaway, N., Dimova, N., Cuny, G. D., and King, R. W. (2010). Pharmacologic inhibition of the anaphasepromoting complex induces a spindle checkpoint-dependent mitotic arrest in the absence of spindle damage. Cancer Cell 18, 382-395.
Zhang, L., Park, C. H., Wu, J., Kim, H., Liu, W., Fujita, T., Balasubramani, M., Schreiber, E. M., Wang, X. F., and Wan, Y. (2010). Proteolysis of Rad17 by Cdh1/APC regulates checkpoint termination and recovery from genotoxic stress. $E M B O J$. 29, 1726-1737.

Zhang, P., Wong, C., Liu, D., Finegold M., Harper, J. W., and Elledge, S. J. (1999). p21(CIP1) and p57(KIP2) control muscle differentiation at the myogenin step. Genes Dev. 13, 213-224.

Zheng, L., Chen, Y., and Lee, W. H. (1999). Heclp, an evolutionarily conserved coiled-coil protein, modulates chromosome segregation through interaction with SMC proteins. Mol. Cell. Biol. 19, 5417-5428.

Zheng, N., Schulman, B. A., Song, L. Miller, J. J., Jeffrey, P. D., Wang, P., Chu, C., Koepp, D. M., Elledge, S. J., Pagano, M., Conaway, R. C., Conaway, J. W., Harper, J. W., and Pavletich, N. P. (2002). Structure of the Cul1-Rbx1-Skp1-F boxSkp2 SCF ubiquitin ligase complex. Nature 416, 703-709.

Zhou, H., Kuang, J., Zhong, L. Kuo, W. L., Gray, J. W., Sahin, A., Brinkley, B. R., and Sen, S. (1998). Tumour amplified kinase STK15/BTAK induces centrosome amplification, aneuploidy and transformation. Nat. Genet. 20, 189-193.

Zhu, L., and Skoultchi, A. I. (2001). Coordinating cell proliferation and differentiation. Curr. Opin. Genet. Dev. 11, 91-97.

Zhu, Q., Pearson-White, S., and Luo, K. (2005). Requirement for the SnoN oncoprotein in transforming growth factor beta-induced oncogenic transformation of fibroblast cells. Mol. Cell. Biol. 25, 10731-10744.

Zhu, W., and Depamphilis, M. L. (2009). Selective killing of cancer cells by suppression of geminin activity. Cancer Res. 69, 4870-4877.

Zibat, A., Missiaglia, E., Rosenberger, A., Pritchard-Jones, K., Shipley, J. Hahn, H., and Fulda, S. (2010). Activation of the hedgehog pathway confers a poor prognosis in embryonal and fusion gene-negative alveolar rhabdomyosarcoma. Oncogene 29, 6323-6330.

Conflict of Interest Statement: The authors declare that the research was conducted in the absence of any commercial or financial relationships that could be construed as a potential conflict of interest.

Received: 30 November 2011; paper pending published: 15 December 2011; accepted: 22 December 2011; published online: 09 January 2012.

Citation: Penas C, Ramachandran V and Ayad NG (2012) The APC/C ubiquitin ligase: from cell biology to tumorigenesis. Front. Oncol. 1:60. doi: 10.3389/fonc. 2011.00060

This article was submitted to Frontiers in Molecular and Cellular Oncology, a specialty of Frontiers in Oncology. Copyright (C) 2012 Penas, Ramachandran and Ayad. This is an open-access article distributed under the terms of the Creative Commons Attribution Non Commercial License, which permits noncommercial use, distribution, and reproduction in other forums, provided the original authors and source are credited. 